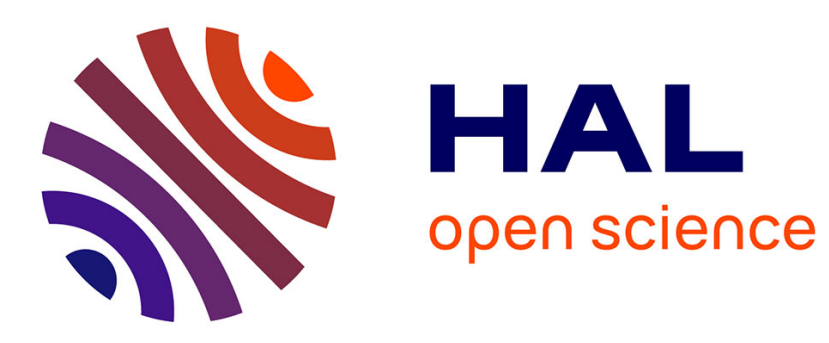

\title{
GM and non-GM supply chain co-existence and traceability: context and perspectives
}

\author{
Yves Bertheau
}

\section{To cite this version:}

Yves Bertheau. GM and non-GM supply chain co-existence and traceability: context and perspectives. Genetically modified and non-genetically modified food supply chains: co-existence and traceability, Wiley-Blackwell, 2013, 9781444337785. 10.1002/9781118373781.ch32 . hal-02810137

\section{HAL Id: hal-02810137 https://hal.inrae.fr/hal-02810137}

Submitted on 6 Jun 2020

HAL is a multi-disciplinary open access archive for the deposit and dissemination of scientific research documents, whether they are published or not. The documents may come from teaching and research institutions in France or abroad, or from public or private research centers.
L'archive ouverte pluridisciplinaire HAL, est destinée au dépôt et à la diffusion de documents scientifiques de niveau recherche, publiés ou non, émanant des établissements d'enseignement et de recherche français ou étrangers, des laboratoires publics ou privés. 


\title{
32
}

\section{GM and Non-GM Supply Chain Co-Existence and Traceability: Context and Perspectives}

\author{
Y. Bertheau
}

\subsection{INTRODUCTION}

It would seem impossible to discuss the co-existence and traceability of GMO and non-GMO supply chains in Europe without reviewing (i) certain issues which have led to their rejection by most citizens, whether or not they are socially or politically active, and (ii) the changes in agricultural production over the last few decades.

The failure of scientists and companies to understand this rejection of GMOS can be explained to an extent by the social questioning of the advantages of GMOs and, more generally, of various technological innovations and the uncertainty surrounding them, not to mention continuing related conflicts such as patentability.

\subsection{BACKGROUND}

\subsubsection{Expertise}

Market authorisations of GMOs are based on prior assessments of their health and environmental risk, conducted by national or international scientific panels, with varying levels of standardisation and attempts to reach a consensus (Bergmans, 2006; Codex Alimentarius, 2003; EFSA GMO Panel, 2008, 2010, 2011b; Kleter and Kok, 2010). The same panels of experts decide on co-existence regulations and ensure that the notifier's recommendations correspond to mandatory guidelines in terms of surveillance plans, while external experts may be called in to contribute.
While it enjoys the experience of previous expertise (drugs, chemical molecules), the assessment of health and environmental risks related to GMOs has progressed from a mainly molecular-based approach to a more systemic approach, admittedly with increasingly complex requirements, but which are not merely the sum total of lower levels (Anderson, 1972). Experts have learned how to assess GMO risks 'as they go', by gradually incorporating new data and requests. This, however, is far from providing the answers to all the questions that arise (Bonneuil and Joly, 2007).

\subsubsection{Hard science versus soft science}

The social, economic and ethical aspects of market authorisations are not taken into account in scientific assessments, whereas they are the reasons behind most of the opposition encountered.

Until recently, only Norway included social criteria such as sustainable development or advantages for developing countries in its assessments. This attempt to achieve a systemic approach is not without its (many) problems (Direktoratet for naturforvaltning, 2009; Kvakkestad and Vatn, 2008). Applications do not include such considerations, which are not provided due to the lack, for example, of EC obligations in cases where the request comes from a single country. This continuous work has to be distinguished from occasional reports of advisory committees

Genetically Modified and Non-Genetically Modified Food Supply Chains: Co-Existence and Traceability, First Edition. Edited by Yves Bertheau. (C) 2013 Blackwell Publishing Ltd. Published 2013 by Blackwell Publishing Ltd. 
on GMOs on socio-economic issues, such as the reports of the Dutch COGEM or British ACRE (COGEM, 2009).

The latest European recommendation on co-existence (2010) enables Member States to include social and economic criteria in their definition of their co-existence measures. It is regrettable that the European Commission did not take this further by requiring that applicants provide social and economic data with regard to the relevance of GMOs in their applications.

France has only recently created an Economic, Ethical and Social Committee (CEES) in addition to the Scientific Committee (CS) at the Haut Conseil des Biotechnologies (HCB, High Council for Biotechnologies) (Bertheau and Davison, 2011). This CEES discusses social and economic issues and includes politicians, stakeholders and three 'qualified experts' to draw up its recommendations. For some points a consensus is reached, for others a majority agreement; however the Committee is often criticised for conclusions such as 'some think this... while others think that ... 'S Such criticism is both uncalled-for, given that the system is still new and finding its feet, and above all hypocritical, as such a committee cannot be rightly asked to reach a consensus that society has not successfully reached after more than a decade of debate.

The experiences of this CEES are being observed on a European scale with various countries attempting to identify information that may enable them to encourage public acceptance of GMOs. Similarly, the introduction of economists and a sociologist within the HCB's Scientific Committee (CS) should provide new momentum to its expertise, if only in reference to Bourdieu's views of scientific authority (Bourdieu, 1976, 1997).

Following a short experiment in Britain (http:// webarchive.nationalarchives.gov.uk/20100419143351/ http://www.aebc.gov.uk/), only two countries have begun to take into account society's requirements, which roughly comprise a demand for participatory science and the democratisation of expertise (Ferretti and Pavone, 2009; Lengwiler, 2008). This follows a continuous approach, and is therefore less dependent on the case-by-case basis conducted by scientific bodies in some other countries, but the relevance of such an approach is still fiercely challenged by both scientists and some stakeholders of the HCB.

This demand for the democratisation of expertise is part of a broader, more fundamental social movement affecting a number of fields such as (i) electromagnetic radiation from mobile telephones or ultra-high voltage power lines, (ii) nanotechnologies and (iii) synthetic biology, to name but the most recent. In addition to citizens' conferences, used in the 1970s, this broader expertise is set to provide answers on the general relevance of GMOs for society, a recurring issue in the controversy (Boy et al., 2000).

\subsubsection{Independence and conflicts of interest}

In addition to the European health crises mentioned previously (Bertheau and Davison, Introduction to this book), European citizens are calling into question the quality and independence of scientific expertise. They are concerned as much about certain biases in the expertise and conflicts of interest as lobbies in action and the 'revolving door' system of officials working in bodies of expertise.

This questioning of expertise is also due to the fact that scientific expertise is a social construct, despite this being refuted by 'hard science' scientists (Motion and Doolin, 2007). This social construct is a result of the frame of the expertise, value judgements on the bodies and the values upheld by each scientist on cross-disciplinary subjects. Various authors have stressed how experts very often make decisions on subjects that are at the boundaries of their knowledge, and therefore in an uncertain environment (Edwards, 1999; Joly, 2001; Latour and Woolgar, 1979; Levidow et al., 2005; Levidow and Marris, 2001; Mazur, 1985).

As highlighted by these authors, it would be unrealistic to think that scientific bodies can foresee the future without sufficient distance, background and previous data. The belief that experts have in their ability to project themselves into uncertain situations can only be an obstacle to their stances and stifle acceptance from their audience. These debates on GMOs are related to others on various health products or safety such as in nuclear power plants. The facts can only increase the public's apprehension and distrust in this expertise which, until now, consisted in more or less assuring that risks have been almost totally mastered.

Furthermore, these bodies' scientific expertise puts forward the concept of the established 'sound science', which has been undermined by various frauds and lobbies created by manufacturers to protect their interests, when the scientists themselves are not involved in conflicts of interest (Baba et al., 2005; Crawford-Brown, 2005; Diels et al., 2011; Gaskell and Allum, 2001; Hirsch, 2009; Ong and Glantz, 2001; Reynolds, 2004; van den Belt, 2003; Wertz et al., 2011). This 'sound science', a favourite among politicians such as the former US President G.W Bush and notifying companies, no longer enjoys the public's trust, while the public continues to have high hopes for scientific progress.

These various criticisms are also supported by attempts to reach a 'consensus' on scientific expertise, which runs 
the risk of poor assessments in situations of uncertainty (Levidow and Carr, 2007). This consensus desired by scientific bodies results, in particular, in the scientists themselves being doubted, as they are seen by the public as champions of an ideology, for example 'productivism' or 'scientism', and as a social body that defends its own interests. Most people therefore consider this 'consensus' to have been created at the expense of complexity and transparency. Moreover, the public can easily sense that this construction involves a certain contempt for citizens, who are deemed unable to sufficiently understand the great science and are condemned to live with uncertainty (Frewer et al., 2003; Gisler and Kurath, 2011; House et al., 2003; Joly et al., 2000; Kolstø, 2001; Levidow, 2003; Levidow and Carr, 2007; Marris et al., 2005; Marris et al., 2001).

In doing so, they echo sociologists, anthropologists and philosophers, including Habermas, in considering the idea that an expert procedure cannot be separated from moral considerations and values and be solely based on specialist knowledge (Habermas, 1971; Harding, 1992; Merton, 1973; Turner, 2001).

As stressed by Pierre Muller: 'the more complex a decision to take, the more political it is'; science is therefore often called upon to 'solve' social problems (Muller, 1995).

Expertise, just as science or technological innovation, therefore is not neutral, pure or impartial (Bourdieu, 1976, 1997).

\subsubsection{Expertise and counter-expertise}

This phenomenon of rejection of a certain type of expertise has only intensified with increasingly easy access to diverse and contradictory sources of information (discussion forums, blogs, social networks, etc., all powerful, fast and uncontrollable), fuelled by civil society's growing capacity for counter-expertise. This set of facts and beliefs (the latter not to be assimilated to conventional unfounded rumours) has led a large number of citizens to reject scientific 'truth' upheld by experts.

This scientific 'truth' is also undermined by its possible transmission through the actions - 'publicity' according to some stakeholders - of industrial lobbies who do not sufficiently consider the fears and demands of society (Delborne, 2008; Levidow and Marris, 2001; Miller and Harkins, 2010; Miller and Conko, 2004; Prat, 2011).

With information flow to consumer citizens constantly increasing, the recipients of this information are now filtering it more. This break, due to the growing importance of the recipient, means that communication is now more like a negotiation than knowledge transmission or sharing. Citizens have become active players in their information consumption and are considering the information received and exchanged with wider perspectives, particularly if it comes with an argument of authority. They therefore favour exchanges within their communities, in which they place their trust. Communication failure has consequently become the outcome of scientific expertise communication, while certain citizens' demands for participatory expertise generally aim at what they consider a necessary adaptation of the proposed innovations.

The comitology of expertise is a long process, into which the new facts with an impact on risk assessment can only be incorporated slowly and belatedly (see for example: Vaucheret and Chupeau, 2012; Zhang et al., 2012). The necessary time frame for the standardised incorporation of new questions into expertise procedure can only surprise citizens. These new questions may cast doubts on past expertise and come up against the impossibility of asking applicants to provide additional studies for the applications already submitted.

These delays in scientific expertise result in concern and distrust from lay citizens, further fuelled by 'scaremongers' that experts often admonish as being the cause of 'unfounded fears'.

\subsubsection{Scientists and lay people}

With the non-consideration of this reality in which citizens have lost some of their respect for scientific experts who are seen as subservient to 'scientism' and defending their personal values with regard to progress and productivism, the current controversy on GMOs can only reach a deadlock. This is what the Eurobarometers and other opinion polls reveal as regards both GMOs and science itself (Bucchi and Trench, 2008; Gaskell et al., 2005; Gaskell et al., 2010; Richard, 2011). When it comes to technological innovations, citizens now place their trust more readily in associations than in other information sources.

We are stuck in a situation in which scientists are from Mars and citizens are from Venus, to paraphrase Christoforou (2003). The non-inclusion of social factors in the GMO controversy is a major stumbling block.

It is fitting to consider the questioning of recommended co-existence measures in light of these general doubts surrounding scientific and technical expertise. These points are often considered by decision-makers and explain public authorities' choice of co-existence measures, but various authors deem them to be inconsistent with the European principle of 'proportionality'. 
In this many-sided debate, farmers, who remained relatively quiet and in the background for the first decades of the twentieth century, are now voicing their differences and questions about these agricultural innovations that may conflict with other land uses demanded by society (cf. Introduction of this book).

\subsubsection{Agricultural productions and supply chains}

Agricultural supply chains have undergone significant change over the twentieth century, basically evolving from subsistence-based farming in countries with a high-density agricultural population, at least for Europe, to industrialised production, an active sector of the market economy with a falling number of farmers and more futures markets, currently with increasingly speculative trends (Montfort, 2008). While this change is clearly visible in Western areas such as the USA, Europe, Russia and former Soviet countries, and some Asian countries such as Japan and China and others in Latin America, it has also affected many developing nations in Africa and less developed parts of Asia.

Over the last century, agricultural supply chains have been subjected to various technical changes, that have been more or less well accepted, with, for instance, the introduction of mechanical ploughing, a rise in the use of inputs and certified seeds - with increasingly hybrid varieties that must be purchased each year (Federico, 2008; Hurt, 2002; Mazoyer and Roudart, 2006).

This increase in agricultural production has also come together with more specialised productions; when niche markets are not the chosen path the signs of Taylorism and Fordism are often felt with resentment (Bonanno and Constance, 2001; Bonneuil and Thomas, 2009; Wolf, 2008). The necessary investments have led farmers to contract significant debt, resulting in financial instability (Agreste, 2010, 2011; Estenson, 1987; Pietola et al., 2011; Shepard and Collins, 1982).

The development of international trade in agricultural products has brought about a race for farmers to be competitive in order to withstand the increased competition. This need for competitiveness has generally been supported by export subsidy policies such as those in the USA and Europe. International trade has, for example, resulted in Senegalese rice being replaced by American broken rice in the national dish. This specialisation has also resulted in a reduction in the number of species grown, the erosion of the genetic diversity of cultivated varieties and an increase in the number of orphan species, through crop improvement and environmentally-friendly farming practices (Frankel and Hawkes, 2011; Moose and Mumm, 2008; Tadele, 2009).

A large-scale rural exodus also saw a drop in the number of farms in 'disadvantaged' areas such as mountain regions and the extension of farms in other regions with more 'competitive' farming methods. The average surface area of farms has constantly increased in Western Europe. In France for example, it was 10-20ha in the nineteenth century, 20-40 ha in 1950 and is currently at 30-100 ha. The 200000 farms over 40 ha accounted for almost $75 \%$ of French farmland in 2001 and the trend has continued since. This phenomenon was first observed in Western European Member States is now visible in Eastern Member States.

This extension of total cultivated area per farm has naturally led farmers to cut the time it takes to farm one unit of land, particularly when the farmer or spouse must also have a second paid activity, which is very common (Briggeman, 2011; Delame and Thomas, 2007). GMOs were clearly a welcome means of reducing workloads.

At the same time, the development of international trade in agricultural products also resulted in a reduction in the number of operators (Green and Hervé, 2006). These are players in the agricultural commodity mass markets and in niche markets such as the European non-GMO market. Production specialisation, often conducted at the expense of farmers in developing countries, has made the Americas the leading net exporters of agricultural commodities, in particular for mass-produced animal feed. Similar specialisation attempts for exports have been made in countries with large fertile plains such as the Ukraine, where arable land has been sold or leased to agricultural conglomerates.

While being encouraged to produce more, farmers also face other demands such as the removal of the most toxic molecules and the reduction of inputs (European REACH Directive, Ecophyto 2018 in France, etc.). These demands, often summed up under the term 'intensively ecological' agriculture, are the subject of debate among farmers and more generally in society.

The restructuring of farms has turned the rural environment of a stable and reassuring social framework into a precarious and constantly changing environment. This is the case even in Eastern Member States such as Romania, where large cooperative farms have survived. Lastly, as the total cultivated area per country drops due to increasing urbanisation, real estate pressure, and therefore tension and competition, are on the rise for these areas as for yields. 
It is against this backdrop of tense competitiveness and specialisation that farmers must select their production methods. Farmers torn between contradictory demands and conflicting production options are common in this context. This situation influences their position and view of GMOs. This is why those who are against GMOs speak of risks to the great displeasure of those who are in favour of them.

\subsection{3 'Feeding the world'}

Feeding the world has always been the challenge for agriculture, while it has not prevented climate- or economyrelated famines, as noted by $\mathrm{C}$. Walford as early as the nineteenth century, in his description of more than 350 famines (Brun and Dupin, 1975).

Farmers are the suppliers of foodstuffs that are now distributed on a global scale. Demographic growth has brought about serious food crises, such as the hunger riots of 2007-2008, or those projected by various models including those of the Club of Rome in the 1970s (Bell, 2009; Colombo, 2001; Evenson and Gollin, 2003).

These gloomy forecasts, which did not prove correct, perhaps because the models were erroneous or because solutions were found such as the green revolution of the 1970s, are once again topical with the global population expected to reach nine billion by 2050 (although some demographers have called this estimation into question) (Dahan-Dalmedico, 2007; Dahan-Dalmedico and Armatte, 2004; Lutz et al., 2001; Sauvy, 1949; UNFPA (United Nations Population Fund), 2011; United nations Conference on Trade and Development, 2011a, b; Vieille Blanchard, 2010).

The forecast with regard to available arable land to feed this increasing population varies between regression to a slight improvement, but in poorer soil and climate conditions.

Two arguments have then re-emerged in political and agricultural circles on the 'feeding the world' issue and farmers find themselves between the two. One involves attempting to double farm production by continuing to improve yields and cultivated hectarage, while the second favours the reorientation of production types and of the global development and consumption model (Drogué et al., 2006; Foley et al., 2011; Godfray et al., 2010; Juma, 2011; Paillard and Treyer, 2010; Paillard et al., 2011).

In the first case, GMOs would enable a clear rise in production through increased yields and crops suited to unfavourable cultivation conditions (drought, high salinity in soils, etc.). This scenario is underpinned by a vision concerned with improving the well-being of populations based on economic growth in line with current trends and in which GMOs naturally have their place.

In the second case, generally championed by agricultural development specialists and agronomists in particular, authors identify various factors other than agricultural production as causes of past, present and future famines. They highlight in particular that the majority of people suffering from famine are actually farmers. They also note the low level of support that local agriculture received due to the development of an international trade in foodstuffs from developed nations and countries with export subsidies.

These authors also denounce the fact that farmers in developed countries are urged to turn to other, non-food productions, with a view to developing supply chain trade and finance. Here is a common example: almost $40 \%$ of US maize is used for the production of bio-fuels on fertile land while these bio-fuels are of little agro-environmental interest and have a generally negative energy balance (inputs for production versus energy recovered after harvest) (Bringezu et al., 2012; FAO, 2008; Landeweerd et al., 2009; Searchinger et al., 2008). This observation seems to have been taken into account in the USA, where bio-ethanol subsidies have recently ceased. This decision is probably not unrelated to the improvement of US energy independence following increased production of unconventional oil and shale gas.

International trade in agricultural commodities, in addition to the strong development of futures markets and speculation, is one of the factors causing the high price volatility, and even some of the famines, in recent years. These authors stress the close relationship between areas of famine and situations of conflict or corruption which reportedly prevent the excess production of some areas being transported in time to starving, often displaced, populations. In light of this increased global agricultural specialisation, they recommend returning to local production and alternative methods with an increase in income for local populations.

In these scenarios, GMOs are either not considered or rejected, as they do not meet the needs of low-income populations and would even increase their dependence on inputs, marketed seeds, and in turn companies.

Both scenarios present almost identical considerations as those put forward by the 'green revolution', whose balance sheet has received mixed reactions from the authors (Alessandrini, 2010; Bishaw and Turner, 2008; 
Evenson and Gollin, 2003; Huang et al., 2002; Paul. et al., 2003; Ruttan, 2004; Swaminathan, 2010).

It seems as though GMO supporters have not learned from the controversial recent past, in terms of their positions or the communications means implemented. Since the same causes produce the same effects, it is inevitable that these positions are surrounded by tension in terms of the major issue of world hunger despite the overproduction of the last decades.

Faced with industrialised agriculture (for example through animal production dependent on soybean and maize produced on very large areas), other farmers, often criticised as 'opting for' decline and having a backwardlooking vision of agriculture, have no choice but to conduct publicity stunts such as destroying GMO crops, and such acts are related to a history of resistance and radicalism. The difference in available resources, financial in particular, between these two visions of agriculture, and more generally of society, is one of the causes of those positions that are deemed extreme. Civil disobedience follows on in a new construction of legitimacy, including scientific, arguing for a state of emergency and necessity (Doherty and Hayes, 2012; Hayes, 2007; Seifert, 2006; Seifert, 2009).

Among the other factors that play a part in farmers' choice of GM or non-GM crops is the need to maintain multiple production methods. A particular type of technological pluralism that means, as illustrated for the energy mix, that the availability of electric light does not prevent some from continuing to light candles if they so wish (Hermitte, Chapter 23 this book).

Farmers must make their own decisions based on their cost-benefit analysis, which in reality is almost impossible. The methodology and structure of this type of analysis approach are still under discussion, particularly for quantitative approaches (Morris, 2011). Farmers therefore make contradictory demands: the conventional request for preserved freedom but within a framework providing protection. They often base themselves on regulations and laws, even if it means using various levers to arrive at the most favourable result for themselves.

Rather than aiming to feed the world, economic opportunities override in the choice of production methods and land use. Because of this, the subsidies, while increasingly decoupled, of the European CAP or US exports model the agricultural landscape (Alstom, 2007; Bock et al., 2002; Mayrand et al., 2003; Russo, 2009; Young and Westcott, 2000). The need to secure income also explains the success of gene stacking, similar to blanket phytosanitary treatments being used instead of simply using treatments when necessary.
It should also be pointed out that some of the differences in European farmers' behaviour in comparison to most of their American counterparts could also be related to differences in the availability of land not used for agriculture. The USA has very large natural parks, whereas agriculture is everywhere in the landscapes of the EU and some Asian countries. Hence the use of concepts in the EU such as 'high nature value' or the desire of some farmers to openly display their attachment to their land and local traditions, which are uncommon in the USA as farmers take more distance from their land, considering it merely as a means of production. These considerations have also been noted by society and may go some way to explaining the positions of some farmers.

These differences in the acceptance of agricultural innovations such as GMOs have resulted in separate production supply chains that must provide traceability to satisfy consumers. This implies the ability to produce and segregate products from the different production methods and to ensure fair practices in the food trade and consumer information.

\subsection{CO-EXISTENCE}

Going beyond storage in silos, co-existence of supply chains is generally considered to be sufficiently controlled by companies. The actual costs of co-existence remain unknown, a fact that is not specific to GMO and non-GMO supply chains. In theory, the question of who should bear the resulting additional costs will be valid for a long time to come and in practice will be answered by non-GMO supply chains.

The notion of co-existence between GMO and nonGMO crops is a mainly European one, in that it is organised by public standards. Co-existence, between GM and for example organic farming, and damages paid for economic losses are recent topics of debate in the USA, despite the lack of labelling for GMO products and the common use of private identity preservation (IP) to meet the requirements of exports toward the EU and some Asian countries. This interference is due to the demands of organic farmers, following the authorisation of GM alfalfa, the first perennial to be authorised, but the expected development of molecular farming may also be put forward (Beecher, 2011; Coexistence Working Group et al., December 2003; GMO Compass, 2011; Grossman, 2008; Perkowski, 2011; Smyth and Kershen, 2006; Spök, 2007).

Yet before addressing the issue of co-existence from a purely agricultural standpoint, that is as part of an option to maintain technological pluralism and consumers' 
freedom of choice, it is necessary to review the issue of the in situ preservation of genetic diversity. The latter, which is mainly dynamic, is still required to improve varieties and cannot be dependent on banks of frozen genes.

\subsubsection{GMOs and genetic resources}

While the EU is a diversification centre for some crops, such as sugar beet for which gene exchanges with Beta maritima must be minimised, the question of preserving genetic resources is topical in other parts of the world, such as maize in Mexico.

This example has been selected due to both the large surface areas of GMO maize cultivation in the world and the controversy that has arisen around the preservation of genetic resources in this diversification centre (Foyer, 2010). In addition to the controversy over the possible presence of GMO maize in Mexican farmers' native 'criollo' (landraces) varieties and the risk of contamination of resources preserved at the CIMMYT (International Maize and Wheat Improvement Center: CGIAR), the question of compensation payable to Mexican farmers who have worked for centuries to obtain maize and the varieties currently cultivated is also important.

In more general terms, this question addresses openpollinated crop seeds (also called 'peasants' seeds') obtained through participatory selection (Bocci and Chable, 2008; Osman and Chable, 2009).

The issue of preserving 'peasants' seeds' has been raised relatively little in current works on co-existence. The same applies to redress, financial or other, for GMO presence in these local varieties which have biological features that differ considerably from the hybrid varieties used in coexistence studies.

If it were agreed that diversification centres and crop seeds obtained through participatory selection should be preserved, two points would have to be addressed: (i) which technical measures must be taken to ensure this preservation and who would be in charge, and (ii) which type of compensation would be applied (for this exclusion from an agricultural technological innovation)? Should states provide compensation for local farmers? If so, in what form and to what extent? Should some international bodies compensate these states? This question is related to the more general issue of international demands for the preservation of forest carbon stores, such as the Amazon rainforest, or natural reserves that are sources of biodiversity such as in Honduras, with regard to oil production. The question of ecosystem services has not yet been addressed as co-existence's concern.
If these needs and demands from local populations are not taken into consideration, the battle lines of the GMO controversy will become further entrenched.

\subsubsection{Co-existence conditions}

As already highlighted by many authors and noted in the introduction of this book, co-existence conditions in the field are easier for mainly autogamous crops such as soybean. It is, however, important to remember that autogamy rates never reach $100 \%$ and that some pollinating insects can adapt to new agricultural landscapes. Except for considerations in the monitoring of seed sales, the effectiveness of which has not been proven (the current unauthorised GM rice crops are an example), this always partial autogamy may explain at least part of China's reluctance, as a soybean diversification centre, to grow GM soybean, while retaining its potential to export non-GM soybean at a higher price (Bertheau and Davison, 2011).

The difficulty comes with mainly allogamous crops such as maize and in particular rapeseed (Cawood, 2011) and its feral plants, or perennials such as alfalfa (AgBioWorld, 2011; Bagavathiannan et al., 2011). Many studies have considered how to set up such co-existence, a generally complicated task with costs that are unclear for GMO and non-GMO producers, but always recommend flexible co-existence with the exception of the network of 'GMfree regions' and of a few publications on GMO-free dedicated production areas.

Although they are often favoured by biotechnologists, (cf. the Transcontainer project by de Maagd and Boutilier, Chapter 5 this book), bioconfinement (also called biocontainment) methods such as cleistogamy of rapeseed, or chloroplast transformation techniques, are far from being commercially available. Only a very few bioconfinement techniques are near commercialisation, most are at the research/laboratory stage (Fargue et al., 2006). Moreover, seeds producers/companies generally use bioconfinement methods to produce hybrid seeds or as a tool in plant breeding (thus also making hybrids). It is thus very difficult to believe that seed companies would be accepting of providing these bioconfinement tools to farmers - even under drastic contractual conditions - to facilitate coexistence in the fields. They will probably keep these 'tools' for their own purposes as currently.

Bioconfinement methods have received a bad press since the 'Terminator' affair and it is therefore likely that the social cost of their introduction will prevent their routine use, with the exception of specific cases such as molecular farming (Bustos, 2008; ETC Group, 2007; Masood, 1998). 
Co-existence conditions are therefore difficult to achieve, particularly in the application of the European recommendation that all measures remain 'proportionate to the objectives'. Their definition generally requires modelling to identify the minimum conditions and above all the local conditions, genotype and climate and soil microconditions, and so on which must be considered to ensure flexibility (cf. for example Della Porta et al. 2008). In a general sense, the requirements for co-existence have led to research on gene flow, atmospheric pollen dispersions and knowledge of critical points for production. Yet the reluctance surrounding this expertise still stands.

For all species, these studies include and must consider in their models many parameters such as crop height, the cultivar that emits the pollen, the size of the transmitting and receiving fields, the partial protection of borders around GMO or non-GMO fields, fragmented landscapes, instant and average wind speed, annual pollen emission variations and so on. However, many of the factors required for these studies are not standardised, such as sampling plans, or used, such as real-time quantitative PCR, deployed downstream of the supply chains (Bellocchi et al., this book; Chamecki et al., 2011; Chamecki and Meneveau, 2011; Della Porta et al., 2008; Dupont et al., 2006; Fargue et al., 2005; Helbig et al., 2004; Honnay et al., 2005; Jarosz et al., 2004; Marceau et al., 2011; McLauchlan et al., 2011; Palaudelmàs et al., forthcoming). This series of factors influences gene flow and leads to a never-ending race to refine the models that require a more systemic approach, but which clearly do not fit with the current political tempo (European Committee of the regions, 2007).

No systemic approach has yet resulted from co-existence studies, which have therefore continued to use an expensive and time-consuming case-by-case approach, in which each cultivated taxon requires new efforts and sparks new questions due to its particular features. For example, the persistence of feral plants for rapeseed or the probable rise of volunteers of maize due to climate change (Devos et al., 2011; Schafer et al., 2010; van de Wiel et al., 2011).

\subsubsection{The case of maize}

If we consider maize as an example, it being the most studied crop, it can be noted that despite more than a decade of work, it has not yet been ascertained at what distance the adventitious presence of GMOs would be zero (Della Porta et al. 2008; Luna et al., 2001). While US guidelines require $1.6 \mathrm{~km}$ for total isolation, new results demonstrate the presence of fertile pollen at more than corroborate the empirical observations of pollen clouds noted by seed producers. The isolation distances for seed production were set over a long period of time and may yet prove to be insufficient for 'GMO-free' thresholds of less than 0.9\% (Luna et al., 2001; OECD, 2011). Such dispersal of viable matter over long distances has been commonly observed for pollen and fungal spores (Bannert and Stamp, 2007; Fenart et al., 2007; Glemnitz et al., 2011; Hallenberg and Kúffer, 2001; Knispel and McLachlan, 2010; Luna et al., 2001; Nagarajan and Singh, 1990; Pan et al., 2006; Van de Water et al., 2007; Westbrook and Isard, 1999).

Various models have been developed particularly for pollen dispersal (Allnutt et al., 2008; Angevin et al., 2008; Aylor, 2005; Aylor et al., 2006; Aylor et al., 2003; Bannert, 2006; Beckie and Hall, 2008; Dietiker et al., 2011a; Dietiker et al., 2011b; Flannery et al., 2005; Goggi et al., 2006; Gustafson, 2008; Gustafson et al., 2006; Jarosz et al., 2005; Jarosz et al., 2003; Jarosz et al., 2004; Kawashima et al., 2004; Klein et al., 2003; Lavigne et al., 2008; Lipsius et al., 2006; Loos et al., 2003; Ma et al., 2004; Marceau et al., 2008; Marceau et al., 2011; Viaud et al., 2008; Viner and Arritt, 2010; Weekes et al., 2007 ; Yamamura, 2004). Two major types of modelling can be identified, the consequences of which on practical co-existence measures vary significantly, particularly for 'GMO-free' thresholds of under $0.9 \%$.

These models have not been compared using the same experimental data. This approach would have provided useful information for decision-makers, leading to amended models and a greater consideration of certain elements such as spatialisation (Faivre et al., 2009).

One model, however, stands out for its presence in European reports and its use in decision aids, such as abacuses or other decision support systems (Angevin et al., 2008; Bohanec et al., Chapter 25 this book; Bohanec et al., 2008; Messéan et al., 2006). It nevertheless has many limitations, not to mention the difficulties concerning its practical implementation.

This model for determining co-existence measures was used in a particularly original way in France where the opinion of the French HCB's Scientific Committee (CS) on technical co-existence measures recommends reverting back to the seed/tuber/root units to facilitate co-existence, particularly due to the effect of the HGE (Haploid Genome Equivalent) unit and gene stacking on co-existence capacities (Comité scientifique, Haut Conseil des biotechnologies, 2012). This change in units, at variance with the European recommendation to use the HGE unit, is a problem for fair practice in trading, access to the European 
single market and farmers' compensation. For the latter, the maximum thresholds of adventitious GMO presence would be calculated using seeds in the field, according to gene stacking in surrounding fields, while the HGE unit would be used for the marketing of production downstream of the supply chain. Contrary to what could be expected of a scientific body, this recommendation to change units comes on top of that to disregard measurement uncertainties and sampling errors.

This opinion has come under strong criticism in France, from both scientists and GMO opponents, due to its attempt to artificially reduce the effect of gene stacking on final GMO content. The reaction to this opinion can be summed up as 'breaking the thermometer to bring down the patient's temperature'.

Another grievance concerns the references for some crops which are very old and mostly taken from corporate studies. In addition, the abacuses from this model do not specify the quantiles, and therefore the confidence intervals, for the recommended co-existence measures.

Some scientists and stakeholders have also noted that the recommended approach simply states the shortcomings of prior co-existence studies, if we consider the HCB's Scientific Committee's final recommendation to monitor adventitious presence in the field over several years. This recommendation does not state how farmers can revert to the previous situation in the event of contamination that significantly exceeds projections, particularly in (farmers' own) 'peasants' seeds obtained through participatory selection.

The future of other maize co-existence models remains highly uncertain.

Without casting aspersions on the quality of each of the models, none of which have been evaluated (Wallach et al., 2006), it can be noted that, as for risk assessment, the HCB's Scientific Committee has combined scientific results and non-neutral constructions in order to arrive at a specific social result, such as the diminished effect of gene stacking. This opinion on co-existence is therefore a social construct that is a far cry from pure and neutral scientific expertise (Bourdieu, 1975, 1976, 1997; DahanDalmedico, 2007; Dahan-Dalmedico and Armatte, 2004; Latour and Woolgar, 1979; Vos, 2008). The only possible refutation of the model used in the HCB's Scientific Committee's opinion will be the observation of the effects of recommended co-existence measures, a nationwide experiment that may be difficult to bear in social terms.

The opinion and recommendation of the HCB's Scientific Committee (CS) and Economic, Ethical and Social Committee (CEES) on co-existence in France agree on the recommendation of structures fostering dialogue among 'GMO-free' production players which may result in specific production areas (Comité économique éthique et social, Haut Conseil des biotechnologies, 2012; Comité scientifique, Haut Conseil des biotechnologies, 2012).

The draft order of the French government which has just been submitted to the European Commission for conformity checks only mentions the Community threshold (i.e. $0.9 \%$ ). It provides for a minimum distance of $50 \mathrm{~m}$ of isolation distance between GM and non-GM fields or $9 \mathrm{~m}$ of non-GM corn/maize around GM field. The French government thus did not take into account the 'scientific' advice of the $\mathrm{HCB}$, to use the measurement unit recommended by the EC - that is the HE unit (based on DNA), as the GMO content increases rapidly when GMOs are 'stacked' - but instead used a kernel counting measurement unit, which is not affected by the stacking level.

A European programme, launched in 2012, aims to offer various tools and measures, including a GIS (Geographic Information System) for the implementation of coexistence measures, for maize in particular.

\subsubsection{Models and implementation of co-existence measures}

The scientific community has failed to finalise most of these models and to provide practical tools for public authorities: optimised programmes to reduce calculation times or cloud computing among national or European systems, interfaces with the computers of meteorological services and land registries where possible to avoid wasting implementation time, user-friendly interfaces to facilitate their endorsement by the civil servants whose job it will be to roll out the measures on more local levels, considerations on how to organise the distribution of computers over the territory and interfacing with negotiation tools and so on.

We are far from the practical applications required by politicians in exchange for their finalised research funding.

There is a great risk that these models may have been 'oversold' to political decision-makers, even in the absence of their 'estimation' (validation) with regard to independent data. We must ask whether we are asking too much of these models and whether we expect unreasonable results from them.

There are several imperfections and shortcomings in the models (such as inability to predict the pollen dispersal over a fragmented landscape from results and modelling obtained with a few adjacent experimental fields) - models which, moreover, are generally not 'validated' with independent data not used in the modeling process - used to 
predict pollen flows and thus to establish co-existence measures. Scientists and companies are calling for 'proportionate' measures, as provided for in the European recommendation, though this wish in all likelihood remains unattainable.

Is there a better solution that respects the principle of proportionality other than that of farmers being able to make their own, individual, choices? This could probably be better achieved through improved territorial organisation. Such organisation, with appropriate negotiation structures, is also urgently requested in the HCB CEES' recommendation, in line with the conclusions of the CoExtra research project (European Commission, 2010).

\subsubsection{Co-existence and costs}

Co-existence still raises various questions on various levels.

The first question involves deciding who will pay for co-existence costs along the supply chains. While the European recommendation provides that these costs will be borne by GMO producers for the production step, there is no mention of who should pay downstream.

The Economic, Ethical and Social Committee (CEES) of the HCB has therefore once again raised the issue of co-existence measures' payment along supply chains. A basic principle suggested in the 2003 version of the European recommendation, but not carried over into the 2010 version, was that new entrants, that is GMO producers, pay for the costs incurred by their entry to the market. However, in practice, the provision to date only covers compensation to non-GMO farmers for adventitious presence in their production under very restrictive conditions. In reality, conventional or organic farmers pay the additional costs incurred (analyses, certifications, storage, other segregation aspects along the supply chains). It is therefore unlikely that the supply chain segregation costs will be allocated to GMO producers who argue that nonGMO productions would enjoy the best prices, which effectively means that the additional costs of supply chains' co-existence are passed on to consumers.

A second question concerns the necessary research for determining the co-existence conditions of other crops. The consideration of costs and the duration of the research required to draw up the current models for a single crop, maize, suggests that co-existence in cases of other crop species will not enjoy such in-depth studies. It is likely that a model such as rapeseed will be selected, as it enables various new factors to be considered in the models, such as the effect of insect pollinators, the persistence and flow- as harbours - or along roads leading to storage silos. It seems unlikely, however, that other crops will be studied, such as alfalfa for its perennial character.

As a result, public authorities will once again be forced to take non-proportionate measures, if the political climate requires them to continue to take non-GMO producers into account. Yet will Europe consider the co-existence requirements of wheat, alfalfa or rapeseed, despite external pressure aimed at crop authorisations to maintain the 'competitiveness' of European agriculture?

As stated previously with regard to the preservation of genetic resources and 'peasants' seeds, co-existence between GMO and non-GMO crops cannot be considered simply in terms of its economic dimension of financial redress. Moreover, the European principle of proportionality supposes that the adventitious presence of GMOs in non-GMO crops is reversible. In addition to the lack of scientific data, this is the question surrounding the proportionate management of two crop types.

Having started co-existence studies on certain crops, and in light of international treaties such as the WTO, will Europe have a choice of crops for co-existence? Will it have the will and resources for this? Could the early international recognition of quality signs such as AOC (the French controlled designations of origin) and PGI (Protected Geographical Indication) act as leverage?

\subsection{TRACEABILITY}

\subsubsection{Overview}

Food traceability is completely expected by consumers, who will not suffer shortcomings for reasons of both food safety and the adulteration of expensive niche foodstuffs.

This traceability is now effective for authorised GMOs. European regulations now make the provision of GMO identification and quantification methods mandatory. This European measure facilitates international trade as these methods are provided free of charge to states that are not members of the European Economic Area (EEA). Some third countries that use mass as the unit of measurement of GMO content can also use conversion factors to meet their regulatory requirements.

The question of unauthorised GMOs has changed significantly in the EEA with, for example, the definition of a low level presence (LLP) of GMOs, unauthorised in the EU, for animal feed (EURL-GMFF, 2011; European Commission, 2011; Henshaw, 2011). In addition, more streamlined approaches used by laboratories to detect unauthorised or unknown GMOs have emerged thanks to the ENGL and similar national initiatives (Holst-Jensen et al., in press; 
Ruttink et al., 2010a; Ruttink et al., 2010b; Tengs et al., 2010). European concerns surrounding asynchronous and asymmetric authorisations are now shared with third countries, which bodes well for international harmonisation (GAO (US General Accouting Office), 2008).

The detection of unknown GMOs is based on two approaches: the matrix approach - supported by decision support systems - and differential quantitative PCR. It also enjoys the support of the JRC ${ }^{1}$ (Joint Research Centre) in Ispra and the ENGL (European Network of GMO Laboratories), which now have long-standing experience in this field.

The JRC also takes part in capacity building in developing countries, which can subsequently control imported GMOs based on the databases of the Cartagena Protocol, and check that their exports comply with the regulations in the countries importing them.

This ability to detect GMOs can only improve health safety, unrelated to GMOs, in these countries through the use of concepts, standards and methodologies created for GMOs in other detection areas, such as those of allergens and toxin producing organisms.

\subsubsection{Probable changes}

Several changes can be expected in coming years.

It is probable that the new European regulation on LLPs in animal feed will reopen the discussion on the unit of measurement of GMO content to be used.

The new GMO production methods (meganucleases, oligonucleotides, etc.) will probably require the implementation of other methods, such as LCR or SNPlex, able to detect specific mutations, if the organisms resulting from the use of these new techniques come under Directive 2001/18 or Regulation 1829/2003 or forthcoming legislation (Chaouachi et al., 2008; Lusser et al., 2011).

As some notifiers are having their certified reference materials (CRM) made by the AOCS (American Oil Chemists' Society) rather than the JRC-IRMM (Institute for Reference Materials and Measurements, an institute of the JRC), it is likely that there will be a shortage of calibrants. These may be replaced with plasmids, alternative reference materials, for identifications and quantifications based on GMO inserts' border fragments. Yet these alternative CRM will not replace the ground seeds such as those currently prepared by the JRC-IRMM, in particular for screening methods routinely used for the matrix approach. Laboratories will therefore have to pay more to meet their needs.

The use of thresholds under $0.9 \%$, such as the $0.1 \%$ threshold for French 'GM-free' crops, will also bring about the following: (i) either the production of appropriate calibrants, which can be obtained with plasmids. The currently available detection methods were validated using as a lower limit the $0.1 \%$ value. To be able to quantify below this $0.1 \%$ value, we need to get reference materials below that value but we also need to adapt the methods, which were not developed to work below $0.1 \%$; (ii) Or the use of sub-sampling methods (Berdal et al., 2008; Kobilinsky and Bertheau, 2005; La Mura et al., 2011). One alternative would be that operators continue to use the current contractual system of 'negative PCR' products (Comité scientifique, Haut Conseil des biotechnologies, 2012; European Commission, 2010; Hannachi, 2011). Such quantification requirements around $0.1 \%$ could also be necessary for GMOs in animal feed around the LLP threshold (European Commission, 2011).

Significant efforts must be made to standardise methodologies, decision trees and other decision support systems for the detection of unauthorised and unknown GMOs. Given the cost of international standardisation for the initial standardisation phase (1999-2006), it is highly likely that the standardisation process will go directly through laboratories and focal points such as the JRCIHCP (Institute for Health and Consumer Protection, a JRC institute hosting the European Reference Laboratory for GMO Food and Feed [EURL-GMFF]).

\subsection{CONCLUSION}

Some authors consider GMO crops to be the third agricultural revolution. As with all agricultural innovations, GMOs are rejected by a portion of the population and of producers. This rejection is often misunderstood by scientists in charge of risk assessment or co-existence measures.

Cost-benefit analysis, and more generally social science issues, must be better incorporated into scientific expertise so that society's questioning of the direction taken by farmers, as well as by society as a whole, may be taken into greater consideration. Society as a whole is no longer satisfied with peremptory statements on the absence of known risks or that GMOs are one of the best solutions to 'feeding the world'.

Expertise must also include the impact of agricultural practices' changes, induced by GMO cultivation, which cannot be dissociated from society's choices. One of the many examples illustrating GMO crop issues is the contradictory results with regard to the effective trends of use of quantities of herbicide since the introduction of GMOs (Expertise collective CNRS-INRA, 2011). 
Consequently, the development of resistant insects or weeds has become a normative issue to be incorporated in scientific assessments of the consequences of GMO crop adoption. Until now, such questions were upstaged in a 'chapter' of 'best farming practices' and companies' stewardships and therefore cleared of 'case-by-case' GMO assessments.

Are the current 'case-by-case' assessments still relevant? The probable introduction of crops for molecular farming will certainly further exacerbate these doubts, as will the recent developments in epigenetics and the observation of animal gene regulation by microRNA of ingested crops.

Society's increasing demands for transparency and participatory assessments cannot be brushed aside by scientists. As information circulates at an ever faster rate, this general demand for participatory expertise in relation to associations' increasing capacity to develop counterexpertise must be taken into account in the field of scientific expertise. The creation of two bodies, one scientific and the other made up of stakeholders, can only contribute to finding a solution if the two bodies work closely together. This is far from the case in the unique, French, experimentation we know.

These questions from society are clearly noted by farmers who consequently question production types (commodities or niche markets) according to economic opportunities and social trends.

Co-existence between GMO and non-GMO crops must be achieved through specific and general surveillance plans for human and environmental health, the guidelines of which have changed in recent years (EFSA GMO panel, 2006, 2011a; European Commission, 2009). Society will therefore have to bear new additional post-marketing costs, due to the use of private products with only a few benefit holders. As is the case with other health or phytosanitary products, the question arises of who will bear these additional costs (Cowan, 2011). A question rather similar to the one about the tragedy of the commons (Hardin, 1968).

Many studies have already began on a national level and also as part of a recently launched European research project (ACRE, 2004; Amanor-Boadu, 2004; Anonymous, 2009; Beckie et al., 2010; Carpenter, 2011; Collier and Mullins, 2010; Deng et al., 2008; Devos, 2008; Environment Agency Austria Umweltbundesamt, 2011; Graef, 2009; Hawes et al., 2010; Hepburn et al., 2008; Marvier et al., 2007; Pascher et al., 2011; Reuter et al., 2010; Sanvido et al., 2007; Sanvido et al., 2011; Schmeller and den Brink et al., 2010; Wal et al., 2003; Wolt et al., 2010; Zughart et al., 2008). The relevance of such specific and general surveillance plans is clear with regard to observations in various third countries (Adler, 2011; Bagavathiannan et al., 2011; Davis et al., 2008; Krupke et al., 2009; Lu et al., 2010; Marquardt et al., 2008; Schafer et al., 2010).

General surveillance plans might be used as part of more general biovigilance plans, and therefore territory surveillance plans (Alcalde, 2006; Bartsch et al., 2006; Bartsch et al., 2007; Delos et al., 2007; Directions régionales de l'agriculture et de la forêt -Service régional de la protection des végétaux des régions Aquitaine et MidiPyrénées, 2007; Environment Agency Austria Umweltbundesamt, 2011; Hintermann et al., 2002; Kleppin et al., 2011; Ministerio de medio ambiente y medio rural y marino. Spain, 2011; Monkemeyer et al., 2006; Paré-Chamontin, 2010; Public Health Agency of Canada, 2002; Schmidtke and Schmidt, 2007; Wilhelm et al., 2009). It is however likely, given current cases and practices, that the costs of these surveillance plans will be for the most part borne by Member States and only to a small extent by notifiers (Bayer BioScience N.V., 2009; Monsanto Co., 2009a, b; Tinland et al., 2006).

At a time when Member States' resources are continuously diminishing, it can be expected that new public spending incurred without compensation from (consent holder) companies will be poorly received and could rapidly trigger new discord. While one of the reasons why citizens have rejected GMOs is the lack of any apparent direct benefits, it would be necessary to consider larger participation from notifying companies in this postmarketing surveillance, as is the case for the validation of GMO detection methods.

Co-existence and traceability in GMO and non-GMO supply chains, and more particularly in the field, cannot therefore be dissociated from a broader social movement that calls into question technological decisions, social choices and who bears costs (Levidow et al., 2005). What has to a greater extent been understood by politicians, who are more receptive to voters and therefore citizens, needs to be taken further into account by scientists.

Yet, does science have its place in public debate?

\section{REFERENCES}

ACRE. 2004. ACRE Guidance Note 16. Guidance on best practice in the design of post-market monitoring plans in submissions to the Advisory Committee on Releases to the environment. Guidance for applicants seeking permission to release genetically modified crops into the environment 
(under Directive 2001/18/EC), pp. 21. Available at: http:// www.bfn.de/fileadmin/MDB/documents/ACRE_2004_ Post-market_Guidance.pdf [accessed 1 May 2012].

Adler J. 2011. The growing menace from superweeds. Scientific American, 304: 74-79.

AgBioWorld. 2011. Vilsack's defense; using property rights is a trick; USDA sending mixed signals; splice of life; insurmountable obstacle. Available at: http://www. agbioworld.org/newsletter_wm/index.php?caseid=archive \&newsid=3042 [accessed 1 May 2012].

Agreste. 2010. Le passif et l'endettement. Les dossiers, 9: 43-46. Available at: http://www.agreste.agriculture.gouv.fr/ IMG/file/rica2010fichef.pdf [accessed 1 May 2012].

Agreste. 2011. Le passif et l'endettement. Les dossiers, 12: 37-40. Available at: http://agreste.agriculture.gouv.fr/IMG/ pdf_rica2011fichef.pdf [accessed 1 May 2012].

Alcalde E. 2006. Post-market monitoring plans of Bt-176 in Spain: 1998-2005. J. Verbrauch. Lebensm., 1: 102105.

Alessandrini D. 2010. GMOS and the crisis of objectivity: nature, science and the challenge of uncertainty. Soc. Leg. Stud., 19: 3-23.

Allnutt T.R., Dwyer M., McMillan J., Henry C. and Langrell S. 2008. Sampling and modeling for the quantification of adventitious genetically modified presence in maize. J. Agr. Food Chem., 56: 3232-3237.

Alstom J.M. 2007. Benefits and beneficiaries from U.S. farm subsidies. Paper prepared for the American Enterprise Institute project on Agricultural Policy, directed by B. Gardner and D.A. Sumner. (University of California, Davis, USA). pp. 65. Available at: http://aic.ucdavis.edu/research/ farmbill07/aeibriefs/20070515_alstonSubsidiesfinal.pdf [accessed 1 May 2012].

Amanor-Boadu V. 2004. Post-market surveillance model for potential human health effects of novel foods. Food Policy, 29: 609-620.

Anderson P.W. 1972. More is different. Science, 177: 393396.

Angevin F., Klein E.K., Choimet C., Gauffreteau A., Lavigne C., Messéan A. and Meynard J.M. 2008. Modelling impacts of cropping systems and climate on maize cross-pollination in agricultural landscapes: The MAPOD model. Eur. $J$. Agron., 28: 471-484.

Anonymous. 2009. Proceedings of the workshop on post market environmental monitoring of genetically modified plants: from data to conclusions - Next steps towards monitoring practice. J. Verbrauch. Lebenms., 3: 1-63.

Aylor D.E. 2005. Quantifying maize pollen movement in a maize canopy. Agr. Forest Meteorol., 131: 247-256.

Aylor D.E., Boehm M.T. and Shields E.J. 2006. Quantifying aerial concentrations of maize pollen in the atmospheric surface layer using remote-piloted airplanes and Lagrangian stochastic modeling. J. Appl. Meteorol. Climatol., 45: 1003-1015.
Aylor D.E., Schultes N.P. and Shields E.J. 2003. An aerobiological framework for assessing cross-pollination in maize. Agr. Forest Meteorol., 119: 111-129.

Baba A., Cook D.M., McGarity T.O. and Bero L.A. 2005. Legislating 'sound science': the role of the tobacco industry. Am. J. Public Health, 95: S21-S27.

Bagavathiannan M., Gulden R. and Van Acker R. 2011. Occurrence of alfalfa (Medicago sativa L.) populations along roadsides in southern Manitoba, Canada and their potential role in intraspecific gene flow. Transgenic Res., 20: $397-407$.

Bannert M. 2006. Simulation of transgenic pollen dispersal by use of different grain colour maize. Diss. ETH No. 16508. In Institute of Plant Sciences Group Agronomy and Plant Breeding (Zürich, Switzerland, Swiss Federal Institute of Technology), pp. 92. Available at: http://ecollection.ethbib.ethz.ch/view/eth:28859 [accessed 1 May 2012].

Bannert M. and Stamp P. 2007). Cross-pollination of maize at long distance. Eur. J. Agron., 27: 44-51.

Bartsch D., Bigler F., Castanera P., Gathmann A., Gielkens M., Hartley S., Lheureux K., Renckens S., Schiemann J., Sweet J. and Wilhelm R. 2006. Concepts for general surveillance of genetically modified (GM) plants: the EFSA position. J. Verbrauch. Lebensmittel., 1: 1520.

Bartsch, D., Gathmann, A., Hartley, S., Hendriksen, N.B., Hails, R., Lheureux, K., Kiss, J., Mesdagh, S., Neemann, G., Perry, J., et al. (2007). First EFSA experiences with monitoring plans. J. Verbrauch. Lebensmittel., 2: 3336.

Bayer BioScience N.V. 2009. Annual report on the general surveillance of MS8, RF3 and MS8xRF3 oilseed rape in the EU, pp. 14. Available at: http://apps2.bvl.bund.de/ bbregwww/doc.do?id=201 [accessed 1 May 2012].

Beckie, H.J., and Hall, L.M. (2008). Simple to complex: modelling crop pollen-mediated gene flow. Plant Sci., 175: 615-628.

Beckie H.J., Hall L.M., Simard M.J., Leeson J.Y. and Willenborg C.J. 2010. A framework for postrelease environmental monitoring of second-generation crops with novel traits. Crop Sci., 50: 1587-1604.

Beecher C. 2011. Biotech alfalfa puts spotlight on coexistence. CheckBiotech, ed. Available at: http://greenbio. checkbiotech.org/news/biotech_alfalfa_puts_spotlight_ coexistence [accessed 1 May 2012].

Bell W. 2009. Foundations of Future Studies. History, Purposes and Knowledge, vol. 1, 5th edition. Transaction Publishers, Piscataway, NJ, USA.

Berdal K.G., Bydler C., Tengs T. and Holst-Jensen A. 2008. A statistical approach for evaluation of PCR results to improve the practical limit of quantification (LOQ) of GMO analyses (SIMQUANT). Eur. Food Res. Technol., 227: 1149-1157. 
Bergmans H. 2006. Basic framework for risk assessment for transgenic plants developed by the OECD: 20 years after the OECD 'Blue Book'. Environ. Biosafety Res., 5: 213-218.

Bertheau Y. and Davison J. 2011. Soybean in the European Union, status and perspective. In: D. Krezhova, (ed.) Recent Trends for Enhancing the Diversity and Quality of Soybean Products. Intech Open Access Publisher, Rijeka, Croatia. pp. 3-46. Available at: http://www.intechopen.com/articles/ show/title/soybean-in-the-european-union-status-andperspective [accessed 1 May 2012].

Bishaw Z. and Turner M. 2008. Linking participatory plant breeding to the seed supply system. Euphytica, 163: 31-44.

Bocci R. and Chable V. 2008. Peasant seeds in Europe: stakes and prospects. Cahiers Agricultures, 17: 216-221.

Bock A.K., Lheureux K., Libeau-Dulos M., Nilsagard H. and Rodriguez-Cerezo E. 2002. Scenarios for co-existence of genetically modified, conventional and organic crops in European agriculture. EUR 20394EN, pp. xi+133. Available at: http://ftp.jrc.es/EURdoc/eur20394en.pdf [accessed 1 May 2012].

Bohanec M., Messéan A., Scatasta S., Angevin F., Griffiths B., Krogh P.H., Znidarsic M. and Dzeroski S. 2008. A qualitative multi-attribute model for economic and ecological assessment of genetically modified crops. Ecol. Model., 215: 247-261.

Bonanno A. and Constance D.H. 2001. Globalization, Fordism, and post-Fordism in agriculture and food: a critical review of the literature. Culture \& Agriculture, 23: $1-18$.

Bonneuil C. and Joly P.B. 2007. Plantes transgéniques, expertise et action publique : évolution de la place et du rôle de la CGB de 1986 à 2006. OCL - Ol. Corps Gras Li., 14: 86-91.

Bonneuil C. and Thomas F. 2009. Genes, Pouvoirs et Profits. Recherche publique et régimes de production des savoirs de Mendel aux OGM. Editions Quae \& Fondation pour le progrès de l'homme, Versailles, France \& Lausanne, Switzerland.

Bourdieu P. 1975. La spécificité du champ scientifique et les conditions sociales du progrès de la raison. Sociologie et sociétés, 7: 91-118.

Bourdieu P. 1976. Le champ scientifique / the scientific field. Actes de la recherche en sciences sociales, 2(2): 88-104.

Bourdieu P. 1997. Les usages sociaux de la science. Pour une sociologie clinique du champ scientifique. Editions Quae, Versailles, France.

Boy D., Kamel D.D. and Roqueplo P. 2000. Un exemple de démocratie participative: la 'conférence de citoyens' sur les organismes génétiquement modifiés. Revue française de science politique, 4-5: 779-810.

Briggeman, B.C. (2011). The Importance of off-farm income to servicing farm debt. Federal Reserve Bank of Kansas
Bringezu S., O'Brien M. and Schütz H. 2012. Beyond biofuels: assessing global land use for domestic consumption of biomass. A conceptual and empirical contribution to sustainable management of global resources. Land Use Policy, 29: 224-232.

Brun T.A. and Dupin H. 1975. Des famines climatiques aux famines économiques (évolution contemporaine des causes et des conséquences des famines). Tiers-Monde, 16(63): 609-630.

Bucchi M. and Trench B. (eds). 2008. Handbook of Public Communication of Science and Technology. Routledge International Handbooks.

Bustos K. 2008. Sowing the seeds of reason in the field of the Terminator debate. J. Bus. Ethics, 77: 65-72.

Carpenter J.E. 2011. Impacts of GM crops on biodiversity. GM Crops, 2: 1-17.

Cawood M. 2011. Whatever the outcome, farmers deserve GM choice, Checkbiotech. Available at: http:// greenbio.checkbiotech.org/news/whatever_outcome_ farmers_deserve_gm_choice [accessed 1 May 2012].

Chamecki M., Gleicher S.C., Dufault N.S. and Isard S.A. 2011. Diurnal variation in settling velocity of pollen released from maize and consequences for atmospheric dispersion and cross-pollination. Agr. Forest Meteorol., 151: 1055-1065.

Chamecki M. and Meneveau C. 2011. Particle boundary layer above and downstream of an area source: scaling, simulations, and pollen transport. J. Fluid Mech., 683: $1-26$.

Chaouachi M., Chupeau G., Berapd A., McKhann H., Romaniuk M., Giancola S., Laval V., Bertheau Y. and Brunel D. 2008. A high-throughput multiplex method adapted for GMO detection. J. Agr. Food Chem., 56(24): 1159611606

Christoforou T. 2003. The precautionary principle and democratizing expertise: a European legal perspective. Science and Public Policy, 30: 205-212.

COGEM (2009). Socio-economic aspects of GMOs building blocks for an EU sustainability assessment of genetically modified crops. COGEM report CGM/090929-01. COGEM (independent scientific advice and information for the Dutch government). pp. 93. Available at: http://ec. europa.eu/food/food/biotechnology/reports_studies/docs/ Netherlands_annex_Cogem_report_en.pdf [accessed 1 May 2012].

Codex Alimentarius 2003. Guideline for the conduct of food safety assessment of foods derived from recombinant-DNA plants. CAC/GL 45-2003. Annex 3: food safety assessment in situations of low-level presence of recombinantDNA plant material in food. Available at: http:// www.codexalimentarius.net/download/standards/10021/ CXG_045e.pdf [accessed 1 May 2012].

Coexistence Working Group: Bertsch K., Basu A., Daws G., Grafton K., Gross R., Hardie W., Hauck D., Jacobson J., 
Nelson D., Sinner R., Schlosser R., Weinlaeder R., Schneiter A. plus proxy for Dale Williams, Theresa Podoll plus proxy for Annie Kirschenmann, Greg Wandrey plus proxy for Luke Bozeman. 2003. Suggested best management practices for the coexistence of organic, biotech and conventional crop production systems. Available at: http://www.ag.ndsu.edu/pubs/plantsci/crops/a1275w.htm [accessed 1 May 2012].

Collier M.J. and Mullins E. 2010. The CINMa Index: assessing the potential impact of GM crop management across a heterogeneous landscape. Environ. Biosafety Res., 9: 135-145.

Colombo U. 2001. The Club of Rome and sustainable development. Futures, 33: 7-11.

Comité économique éthique et social du Haut Conseil des biotechnologies. 2012. Recommandation relative aux conditions d'une coexistence pérenne entre les filières OGM et non OGM, adoptée en séance le 14 décembre 2011. Haut Conseil des biotechnologies, Paris, France. pp. 13. Available at: http://ogm.gouv.fr/IMG/pdf/111221 Recommandation_Coexistence_CEES_HCB_cle0fbdff.pdf [accessed 1 May 2012].

Comité scientifique du Haut Conseil des biotechnologies. 2012. Avis en réponse à la saisine 100506-projet saisine HCB-coexistence sur la définition des conditions techniques relatives à la mise en culture, la récolte, le stockage et le transport des végétaux génétiquement modifiés. Haut Conseil des biotechnologies, Paris, France. pp. 46. Available at: http://ogm.gouv.fr/IMG/pdf/111221_Avis_ CS_Coexistence_Avis_CS_HCB_cle842246.pdf [accessed 1 May 2012].

Cowan T. 2011. Agricultural biotechnology: background and recent issues. In: CRS Report for the Congress, C.R. Service, ed. Washington DC, USA. pp. 46. Available at: http://infousa.state.gov/economy/industry/docs/73949.pdf [accessed 1 May 2012].

Crawford-Brown D. 2005. The concept of 'sound science' in risk management decisions. Risk Management: An International Journal, 7: 7-20.

Dahan-Dalmedico A. (ed.). 2007. Les modèles du futur. Changement climatique et scénarios économiques: enjeux scientifiques et politiques. Editions La Découverte, Paris, France.

Dahan-Dalmedico A. and Armatte M. 2004. Modèles et modélisations, 1950-2000: nouvelles pratiques, nouveaux enjeux / Models and modeling, 1950-2000: new practices, new implications. Revue d'histoire des sciences, 57: 243-303.

Davis V.M., Marquardt P.T. and Johnson W.G. 2008. Volunteer corn in northern Indiana soybean correlates to glyphosate-resistant corn adoption. Crop Management, CM-2008-0721-2001-BR.

Delame N. and Thomas G. 2007. De plus en plus de conjoints d'agriculteurs travaillent hors de l'exploitation. In:
L'agriculture, nouveaux défis - édition 2007. INSEE (Institut National de la Statistique et des Etudes Economiques), Paris, France. pp. 231-244.

Delborne J.A. 2008. Transgenes and transgressions: scientific dissent as heterogeneous practice. Soc. Stud. Sci., 38: 509-541.

Della Porta G., Ederle D., Bucchini L., Prandi M., Verderio A. and Pozzi C. 2008. Maize pollen mediated gene flow in the Po valley (Italy): source-recipient distance and effect of flowering time. Eur. J. Agron., 28: 255-265.

Delos M., Hervieu F., Folcher L., Micoud A. and Eychenne N. 2007. Biological surveillance programme for the monitoring of crop pests and indicators, French devices and European approach compared. J. Verbrauch. Lebensmittels., 2: 16-24.

Deng P., Zhou X., Yang D., Hou H., Yang X., Li Y., Yang Y., Wang X., Fang, S., Wu S. and Liu J. 2008. The definition, source, manifestation and assessment of unintended effects in genetically modified plants. J. Sci. Food Agr., 88: 2401-2413.

Devos Y., Hails R., Messéan A., Perry J. and Squire G. 2011. Feral genetically modified herbicide tolerant oilseed rape from seed import spills: are concerns scientifically justified? Transgenic Res., 21(1): 1-21.

Devos Y.A. 2008. Transgenic crops: a kaleidoscope impact analysis. $\mathrm{PhD}$ thesis. Department of plant production, faculty of bioscience engineering, Ghent University, Ghent, Belgium. pp. 342.

Diels J., Cunha M., Manaia C., Sabugosa-Madeira B. and Silva M. 2011. Association of financial or professional conflict of interest to research outcomes on health risks or nutritional assessment studies of genetically modified products. Food Policy, 36: 197-203.

Dietiker D., Oehen B., Ochsenbein C., Westgate M.E. and Stamp P. 2011a. Field simulation of transgenic seed admixture dispersion in maize with a blue kernel color marker. Crop Sci., 51: 829-837.

Dietiker D., Stamp P. and Eugster W. 2011b. Predicting seed admixture in maize combining flowering characteristics and a Lagrangian stochastic dispersion model. Field Crop. Res., 121: 256-267.

Directions régionales de l'agriculture et de la forêt -Service régional de la protection des végétaux des régions Aquitaine et Midi-Pyrénées. 2007. Culture du Maïs génétiquement modifié en 2007. pp. 22. Available at: http:// ogm.gouv.fr/IMG/pdf/BILAN20072_cle0b2c48-1.pdf [accessed 1 May 2012].

Direktoratet for naturforvaltning. 2009. GMO assessment in Norway as compared to EU procedures: societal utility and sustainable development. Direktoratet for naturforvaltning, Oslo, Norway. pp. 52. Available at: http://www.dirnat.no/ attachment.ap?id=104 [accessed 1 May 2012].

Doherty B. and Hayes G. 2012. Tactics, traditions and opportunities: British and French crop-trashing actions in 
comparative perspective. Eur. J. Polit. Res., On-line first 12 December 2011.

Drogué S., Grandval C., Bureau J.-C., Guyomard H. and Roudart L. 2006. Panorama des analyses prospectives sur l'évolution de la sécurité alimentaire mondiale à l'horizon 2020-2030. MAP 05 G 02 01. Rapport définitif. Adeprina, Paris, France. pp. 119. Available at: http://agriculture.gouv. fr/IMG/pdf/rapport_securite_alim.pdf [accessed 1 May 2012].

Dupont S., Brunet Y. and Jarosz N. 2006. Eulerian modelling of pollen dispersal over heterogeneous vegetation canopies. Agr. Forest Meteorol., 141: 82-104.

Edwards A. 1999. Scientific expertise and policy-making: the intermediary role of the public sphere. Science and Public Policy, 26: 163-170.

EFSA GMO panel. 2006. Opinion of the scientific panel on genetically modified organisms on the post market environmental monitoring (PMEM) of genetically modified plants (Question No EFSA-Q-2004-061). EFSA J., 319: 1-27.

EFSA GMO Panel. 2008. Safety and nutritional assessment of genetically modified plants and derived food and feed: the role of animal feeding trials. Report of the EFSA GMO Panel Working Group on Animal Feeding Trials. Adopted by the Scientific Panel on Genetically Modified Organisms on 12 September 2007. Food Chem. Toxicol., 46: S2-S70.

EFSA GMO Panel. 2010. Scientific opinion. Guidance on the environmental risk assessment of genetically modified plants. EFSA J., 8: 1879.

EFSA GMO Panel. (2011a). Guidance on the post-market environmental monitoring (PMEM) of genetically modified plants. EFSA J., 9: 2316.

EFSA GMO Panel. 2011b. Guidance on the risk assessment of genetically modified microorganisms and their products intended for food and feed use. EFSA J., 9: 2193.

Environment Agency Austria Umweltbundesamt. 2011. Monitoring of genetically modified organisms. A joint policy paper by BfN (Germany), FOEN (Switzerland) and EEA (Austria), S.L. Umweltbundesamt $\mathrm{GmbH}$, Vienna, Austria. pp. 58. Available at: http://www.bfn.de/fileadmin/MDB/ documents/presse/REP0305_1.pdf [accessed 1 May 2012].

Estenson P.S. 1987. Farm debt and financial instability. J. Econ. Issues, 21: 617-627.

ETC Group. 2007. Terminator - La suite. In: Communiqué Mai/juin 2007.pp. 29.Available at: http://www.etcgroup.org/ upload/publication/650/01/etcomm95_tsequel_11june07fr.pdf [accessed 1 May 2012].

EURL-GMFF. 2011. Technical guidance document from the European Union Reference Laboratory for genetically modified food and feed on the implementation of Commission regulation (EC) No 619/2011. JRC-IHCP (ed.). Joint Research Centre, Ispra, Italy. pp. 6. Available at: http:// gmo-crl.jrc.ec.europa.eu/doc/Technical\%20Guidance\%20 from\%20EURL\%20on\%20LLP.pdf [accessed 1 May
European Commission. 2009. Commission decision No 2009/770/EC of 13 October 2009 establishing standard reporting formats for presenting the monitoring results of the deliberate release into the environment of genetically modified organisms, as or in products, for the purpose of placing on the market, pursuant to Directive 2001/18/EC of the European Parliament and of the Council. Official Journal of the European Union, L 275: 9-27.

European Commission. 2010. A decade of EU-funded GMO research (2001-2010). EUR 24473, European Commission (ed.)., European Commission, Brussels, Belgium. pp. 264. Available at: http://ec.europa.eu/research/biosociety/pdf/ a_decade_of_eu-funded_gmo_research.pdf [accessed 1 May 2012].

European Commission. 2011. Commission Regulation (EU) No 619/2011 of 24 June 2011 laying down the methods of sampling and analysis for the official control of feed as regards presence of genetically modified material for which an authorisation procedure is pending or the authorisation of which has expired (Text with EEA relevance). Official Jounal of the European Union, L 166: 9-15.

European Committee of the regions. (2007). Opinion of the Committee of the Regions on the Communication from the Commission to the Council and the European Parliament Report on the implementation of national measures on the coexistence of genetically modified crops with conventional and organic farming. Official Journal of the European Union, L 57: 11-18.

Evenson R.E. and Gollin D. 2003. Assessing the impact of the Green revolution, 1960 to 2000. Science, 300: 758-762.

Expertise collective CNRS-INRA. 2011. Variétés végétales tolérantes aux herbicides. Effets agronomiques, environnementaux, socio-économiques, Beckert M., Dessaux Y., Charlier C., Darmency H., Richard C., Savini I., Tibi A. (eds). INRA-CNRS, Paris, France. pp. 86. Available at: http://www.inra.fr/content/download/31242/386109/ version/1/file/ESCoVTH_rapport-entier_16-12-11.pdf [accessed 1 May 2012].

Faivre R., Leenhardt D., Voltz M., Benoît M., Papy F., Dedieu G. and Wallach D. 2009. Spatialising crop models. In: E. Lichtfouse, M. Navarrete, P. Debaeke, S. Véronique, and C. Alberola (eds) Sustainable Agriculture, Springer, The Netherlands, pp. 687-705.

FAO. 2008. The state of food and agriculture 2008. Biofuels: prospects, risks and opportunities FAO, (ed.). FAO, Rome, Italy. pp. xi+129. Available at: ftp://ftp.fao.org/docrep/ fao/011/i0100e/i0100e.pdf [accessed 1 May 2012].

Fargue A., Colbach N. and Meynard J.M. 2005. Introduction of genotypic effects into GeneSys-RAPE: the example of height and male sterility. Agr. Ecosyst. Environ., 108: 318-328.

Fargue A., Colbach N., Pierre J., Picault H., Renard M. and Meynard J.M. 2006. Predictive study of the advantages of 
cleistogamy in oilseed rape in limiting unwanted gene flow. Euphytica, 151: 1-13.

Federico G. 2008. Feeding the World: An Economic History of Agriculture, 1800-2000. Princeton University Press, New York.

Fenart S., Austerlitz F., Cuguen J., and Arnaud J.F. 2007. Long distance pollen-mediated gene flow at a landscape level: the weed beet as a case study. Mol. Ecol., 16: 3801-3813.

Ferretti M.P. and Pavone V. 2009. What do civil society organisations expect from participation in science? Lessons from Germany and Spain on the issue of GMOs. Sci. Public Policy, 36: 287-299.

Flannery M.-L., Meade C. and Mullins E. 2005. Employing a composite gene-flow index to numerically quantify a crop's potential for gene flow: an Irish perspective. Environ. Biosafety. Res., 4: 29-43.

Foley J.A., Ramankutty N., Brauman K.A., Cassidy E.S., Gerber J.S., Johnston M., Mueller N.D., O'Connell C., Ray D.K., West P.C., Balzer C., Bennett E.M., Carpenter S.R., Hill J., Monfreda, C., Polasky S., Rockstrom, J., Sheehan J., Siebert S., Tilman D., Zaks D.P.M. 2011. Solutions for a cultivated planet. Nature, advance online publication.

Foyer J. 2010. Il était une fois la bio-révolution. Presses Universitaires de France, Paris, France.

Frankel O.H. and Hawkes J.G. (eds). 2011. Crop Genetic Resources for Today and Tomorrow. Cambridge University Press.

Frewer L.J., Hunt S., Brennan M., Kuznesof S., Ness M. and Ritson C. 2003. The views of scientific experts on how the public conceptualize uncertainty. J. Risk Res., 6: $75-85$.

GAO [US General Accountability Office]. 2008. Agencies are proposing changes to improve oversight, but could take additional steps to enhance coordination and monitoring. In: Report to the Committee on Agriculture, Nutrition, and Forestry, US Senate. U.S. Government Accountability Office. pp. 109. Available at: http://www.gao.gov/new. items/d09446.pdf [accessed 1 May 2012].

Gaskell G. and Allum N. 2001. Sound science, problematic publics? Contrasting representations of risk and uncertainty. Politeia, 63: 13-25.

Gaskell G., Einsiedel E., Hallman W., Priest S.H., Jackson J. and Olsthoorn J. 2005. Social values and the governance of science. Science, 310: 1908-1909.

Gaskell G., Stares S., Allansdottir A., Allum N., Castro P., Esmer Y., Fischler C., Jackson J., Kronberger N., Hampel J., Mejlgaard N., Quintanilha A., Rammer A., Revuelta G., Stoneman P., Torgersen H. and Wolfgang Wagner. 2010. Europeans and biotechnology in 2010. Winds of change? A report to the European Commission's Directorate-General for Research. EUR 24537 EN. In Research*EU Studies and reports. European Commission, Brussels, Belgium. pp. 176. Available at: http://ec.europa.eu/public_opinion/ archives/ebs/ebs_341_winds_en.pdf [accessed 1 May 2012].

Gisler P. and Kurath M. 2011. Paradise lost? 'science' and 'the public' after Asilomar. Sci. Technol. Hum. Val., 36: 213-243.

Glemnitz M.G.M., Wurbs A. and Roth R. 2011. Derivation of regional crop sequences as an indicator for potential GMO dispersal on large spatial scales. Ecol. Indic., 11: 964-973.

GMO Compass. 2011. USA: Co-existence - new accents in biotech policy. Available at: http://www.gmo-compass.org/ eng/news/548.docu.html [accessed 1 May 2012].

Godfray H.C.J., Beddington J.R., Crute I.R., Haddad L., Lawrence D., Muir J.F., Pretty J., Robinson S., Thomas S.M. and Toulmin, C. 2010. Food security: the challenge of feeding 9 billion people. Science, 32: 812-818.

Goggi A.S., Caragea P., Lopez-Sanchez H., Westgate M., Arritt R. and Clark C. 2006. Statistical analysis of outcrossing between adjacent maize grain production fields. Field Crop. Res., 99: 147-157.

Graef F. 2009. Agro-environmental effects due to altered cultivation practices with genetically modified herbicidetolerant oilseed rape and implications for monitoring. A review. Agron. Sustain. Dev., 29: 31-42.

Green R. and Hervé S. 2006. IP - Traceability and grains traders: ADM, Bunge, Cargill, Dreyfus. INRA Les cahiers d'ALISS, 03: 1-86. Available at: http://www.prodinra. inra.fr/prodinra/pinra/data/2007/11/PROD200752c85e26_ 20071115125832834.pdf [accessed 1 May 2012].

Grossman M.R. 2008. Anticipatory nuisance and the prevention of environmental harm and economic loss from GMOs in the United States. J. Environ. Law Pract., 18: $107-167$.

Gustafson D.I. 2008. Response to comments by Di Giovanni and Kevan on 'Session V: Estimating Likelihood and Exposure', by Zaida Lentini. Environ. Biosafety Res., 5 (2006) 193-195. Environ. Biosafety Res., 7: 111-113.

Gustafson D.I., Brants I.O., Horak M.J., Remund K.M., Rosenbaum E.W. and Soteres J.K. 2006. Empirical modeling of genetically modified maize grain production practices to achieve European Union labeling thresholds. Crop Sci., 46: 2133-2140.

Habermas J. 1971. Toward a Rational Society: Student Protest, Science and Politics. Heinemann Educational, London, UK.

Hallenberg N. and Kúffer N. 2001. Long-distance spore dispersal in wood-inhabiting Basidiomycetes. Nord. J. Bot., 21: $431-436$.

Hannachi M. (2011). La coopétition au service du bien commun. Les stratégies des entreprises de collecte et de stockage de céréales face aux OGM. In Ecole doctorale CRIT: Culture, régulation, institutions et territoire (Versailles, Université de Versailles Saint-Quentin-enYvelines), pp. 302. Available at: http://www.inra.fr/ 
sciences_action_developpement/content/download/4333/ 45120/version/1/file/These_Hannachi_2011.pdf [accessed 1 May 2012].

Hardin G. 1968. The Tragedy of the Commons, Science, 162:1243-1248.

Harding S. 1992. After the neutrality ideal - Science, politics, and 'strong objectvity'. Soc. Res., 59: 567-587.

Hawes C., Squire G.R., Hallett P.D., Watson C.A. and Young M. 2010. Arable plant communities as indicators of farming practice. Agr. Ecosyst. Environ., 138: 17-26.

Hayes G. 2007. Collective action and civil disobedience: The anti-GMO campaign of the faucheurs volontaires. French Politics, 5: 293-314.

Helbig N., Vogel B., Vogel H. and Fiedler F. 2004. Numerical modelling of pollen dispersion on the regional scale. Aerobiologia, 20: 3-19.

Henshaw C. 2011. EU rule change leads to GM-feed fight. In The Wall Street Journal. New York, USA. January 23, 2011.

Hepburn P., Howlett J., Boeing H., Cockburn A., Constable A., Davi A., de Jong N., Moseley B., Oberdorfer R., Robertson C., Wal J-M, and Samuels F. 2008. The application of post-market monitoring to novel foods. Food Chem. Toxicol., 46: 9-33.

Hintermann U., Weber D., Zangger A. and Schmill J. 2002. Biodiversity monitoring in Switzerland BDM - interim report. Environmental series. No. 342. Swiss Agency for the Environment. Forests and Landscape. (ed.). Berne, Switzerland. pp. 342. Available at: www.umwelt-schweiz. ch/buwal/shop/files/pdf/phpamJ0T6.pdf [accessed 1 May 2012].

Hirsch L.J. 2009. Conflicts of interest, authorship, and disclosures in industry-related scientific publications: the tort bar and editorial oversight of medical journals. Mayo Clin. Proc., 84: 811-821.

Honnay O., Jacquemyn H., Bossuyt B. and Hermy M. 2005. Forest fragmentation effects on patch occupancy and population viability of herbaceous plant species. New Phytol., 166: $723-736$.

House L., Lusk J., Jaeger S., Traill W.B. and Moore M. 2003. Objective and subjective knowledge: impacts on consumer demand for genetically modified foods in the United States and the European Union. AgBioForum, 7: 113. Available at: http://www.agbioforum.org/v7n3/v7n3a03-house.htm [accessed 1 May 2012].

Huang J.K., Pray C. and Rozelle S. 2002. Enhancing the crops to feed the poor. Nature, 418: 678-684.

Hurt R.D. 2002. American Agriculture; Revised Edition: A Brief History. Purdue University Press. pp. 476.

Jarosz N., Loubet B., Durand B., Foueillassar X. and Hubert L. 2005. Variations in maize pollen emission and deposition in relation to microclimate. Environ. Sci. Technol., 39: $4377-4384$.
Jarosz N., Loubet B., Durand B., McCartney A., Foueillassar X. and Huber L. 2003. Field measurements of airborne concentration and deposition rate of maize pollen. Agr. Forest Meteorol., 119: 37-51.

Jarosz N., Loubet B. and Huber L. 2004. Modelling airborne concentration and deposition rate of maize pollen. Atmos. Environ., 38: 5555-5566.

Joly P.-B. 2001. Les OGM entre la science et le public ? Quatre modèles pour la gouvernance de l'innovation et des risques. Economie Rurale, 266: 11-29.

Joly P.-B., Assouline G., Kréziak D., Lemarié J., Marris C. and Roy A. 2000. L'innovation controversée: le débat public sur les OGM en France. Collectif sur les risques (ed.). Institut national de la recherche agronomique [Inra], Grenoble, France. pp. 208. Available at: http://doccem.icllille.fr/Document.htm\&numrec=031060646924240.

Juma C. 2011. Preventing hunger: biotechnology is key. Nature, 479: 471-472.

Kawashima, S., Matsuo, K., Du, M., Takahashi, Y., Inoue, S., and Yonemura, S. 2004. An algorithm for estimating potential deposition of corn pollen for environmental assessment. Environ. Biosafety Res., 3: 197-207.

Klein E.K., Lavigne C., Foueillassar X., Gouyon P.H. and Laredo C. 2003. Corn pollen dispersal: quasi-mechanistic models and field experiments. Ecol. Monog., 73: 131150.

Kleppin L., Schmidt G. and Schroder W. 2011. Cultivation of GMO in Germany: support of monitoring and coexistence issues by WebGIS technology. Environ. Sci. Euro., 23: 4.

Kleter G.A. and Kok E.J. 2010. Safety assessment of biotechnology used in animal production, including genetically modified (GM) feed and GM animals - a review. Anim. Sci. P., 28: 105-114.

Knispel A.L. and McLachlan S.M. 2010. Landscape-scale distribution and persistence of genetically modified oilseed rape (Brassica napus) in Manitoba, Canada. Environ. Sci. Pollu. R., 17: 13-25.

Kobilinsky, A., and Bertheau, Y. 2005. Minimum cost acceptance sampling plans for grain control, with application to GMO detection. Chemom. Intelli. Lab., 75: 189-200.

Kolstø S.D. 2001. Scientific literacy for citizenship: tools for dealing with the science dimension of controversial socioscientific issues. Sci. Educ., 85: 291-310.

Krupke C., Marquardt P., Johnson W., Weller S. and Conley S.P. 2009. Volunteer corn presents new challenges for insect resistance management. Agron. J., 101: 797-799.

Kvakkestad V. and Vatn A. 2008. Regulating the release of GMOs: contrasts between the European Union and Norway. Environ. Plann., C, 26: 968-981.

La Mura M., Allnutt T.R., Greenland A., Mackay I. and Lee D. 2011. Application of QUIZ for GM quantification in food. Food Chem., 125: 1340-1344. 
Landeweerd L., Osseweijer P. and Kinderlerer J. 2009. Distributing responsibility in the debate on sustainable biofuels. Sci. Eng. Ethics, 15: 531-543.

Latour B. and Woolgar S. 1979. Laboratory Life: The Social Construct of Scientific Facts, SAGE Publications, Los Angeles, USA.

Lavigne C., Klein E.K., Mari J.F., Le Ber F., Adamczyk K., Monod H. and Angevin F. 2008. How do genetically modified (GM) crops contribute to background levels of GM pollen in an agricultural landscape? J. App. Ecol., 45: 1104-1113.

Lengwiler M. 2008. Participatory approaches in science and technology. Historical origins and current practices in critical perspective. Sci. Technol. Hum. Val., 33: 186200.

Levidow L. 2003. Precautionary risk assessment of Bt maize: what uncertainties? J. Invertebr. Pathol., 83: 113-117.

Levidow L. and Carr S. 2007. Europeanising advisory expertise: the role of 'independent, objective and transparent' scientific advice in agri-biotech regulation. Environ. Plann. C, 26: 880-895.

Levidow L., Carr S. and Wield D. 2005. EU-level Report. EU regulation of agri-biotechnology: precautionary links between science and policy. Quality of Life and Management of Living Resources. Key Action 111-13: socio-economic studies of life sciences. Project no. QLRT-2001-00034, pp. 76. Available at: http:// technology.open.ac.uk/cts/docs/eu\%20national\%20report $\% 20$ final\%20\%202.pdf [accessed 1 May 2012].

Levidow L. and Marris C. 2001. Science and governance in Europe: lessons from the case of agricultural biotechnology. Sci. Public Pol., 28: 345-360.

Lipsius K., Wilhelm R., Richter O., Schmalstieg K.J. and Schiemann J. 2006. Meteorological input data requirements to predict cross-pollination of GMO Maize with Lagrangian approaches. Environ. Biosafety Res., 5: 151-168.

Loos C., Seppelt R., Meier-Bethke S., Schiemann J. and Richter O. 2003. Spatially explicit modelling of transgenic maize pollen dispersal and cross-pollination. J. Theor. Biol., 225: 241-255.

Lu Y., Wu K., Jiang Y., Xia B., Li P., Feng H., Wyckhuys K.A.G. and Guo Y. 2010. Mirid bug outbreaks in multiple crops correlated with wide-scale adoption of Bt cotton in China. Science 328: 1151-1154.

Luna, S., Figueroa, J., Baltazar, B., Gomez, R., Townsend, R., and Schoper, J.B. (2001). Maize pollen longevity and distance isolation requirements for effective pollen control. Crop Sci., 41: 1551-1557.

Lusser M., Parisi C., Plan D. and Rodríguez-Cerezo E. 2011. New plant breeding techniques. State-of-the-art and prospects for commercial development. EUR 24760 EN. In: JRC scientific and technical reports, European Commission. DG JRC/IPTS (ed.). pp. 220. Available at: ftp://
ftp.jrc.es/pub/EURdoc/JRC63971.pdf [accessed 1 May 2012].

Lutz W., Sanderson, W. and Scherbov S. 2001. The end of world population growth. Nature, 412: 543-545.

Ma, B.L., Subedi, K.D., and Reid, L.M. (2004). Extent of cross-fertilization in maize by pollen from neighboring transgenic hybrids. Crop Sci., 44: 1273-1282.

Marceau A., Guerineau L., Huber L., Angevin F. and Monod H. 2008. Modelling maize pollen emission during the day and the flowering period. Aspects Appl. Biol., 89: 17-22.

Marceau A., Loubet B., Andrieu B., Durand B., Foueillassar X. and Huber L. (2011). Modelling diurnal and seasonal patterns of maize pollen emission in relation to meteorological factors. Agr. Forest Meteor, 151: 11-21.

Marquardt P.T., Krupke C.H., Kruger G.R. and Johnson W.G. 2008. Emergence of adult Diabrotica virgifera virgifera LeConte from volunteer $\mathrm{Bt}$ corn in fields of commercial soybean (Glycine max). In 2008 ESA (Entomological Society of America) annual meeting (Reno, Nevada, USA, ESA). Available at: http://esa.confex.com/esa/2008/ webprogram/Paper37152.html [accessed 1 May 2012].

Marris C., Joly P.-B., Ronda S. and Bonneuil C. 2005. How the French GM controversy led to the reciprocal emancipation of scientific expertise and policy making. Sci. Public Pol., 32: 301-308.

Marris C., Wynne B., Simmons P. and Weldon S. 2001. Final Report of the PABE research project funded by the Commission of European Communities. Contract number: FAIR CT98-3844 (DG12 - SSMI). pp. 113. Available at: http:// csec.lancs.ac.uk/archive/pabe/docs/pabe_finalreport.pdf [accessed 1 May 2012].

Marvier M., McCreedy C., Regetz J. and Kareiva P. 2007. A meta-analysis of effects of Bt cotton and maize on nontarget invertebrates. Science, 316: 1475-1477.

Masood E. 1998. Monsanto set to back down over `terminator' gene? Nature, 396: 503-503.

Mayrand K., Dionne S., Paquin M., and Pageot-LeBel I. 2003. The economic and environmental impacts of agricultural subsidies: an assessment of the 2002 US farm bill \& Doha Round. pp. 76. Available at: http://ictsd.org/ downloads/2008/04/usfarm.pdf [accessed 1 May 2012].

Mazoyer M. and Roudart L. 2006. A History of World Agriculture: From the Neolithic Age to the Current Crisis. London \& Columbia University Press, Earthscan.

Mazur A. 1985. Bias in risk-benefit analysis. Technol. Soc., 7: 25-30.

McLauchlan K.K., Barnes C.S. and Craine J.M. 2011. Interannual variability of pollen productivity and transport in mid-North America from 1997 to 2009. Aerobiologia, 27: 181-189.

Merton R. 1973. The Sociology of Science: Theoretical and Empirical Investigations. University of Chicago, Chicago, pp. 270-277. 
Messéan A., Angevin F., Gomez-Barbero M., Menrad K. and Rodriguez-Cerezo E. 2006. New case studies on the coexistence of GM and non-GM crops in European agriculture. EUR22102 EN, European Joint Research Centre (ed.). JRC-IPTS, Seville, Spain. pp. 116. Available at: http:// www.jrc.es/home/pages/eur22102enfinal.pdf [accessed 1 May 2012].

Miller D. and Harkins C. 2010. Corporate strategy, corporate capture: food and alcohol industry lobbying and public health. Crit. Soc. Policy, 30: 564-589.

Miller H.I. and Conko G. (eds). 2004. The Frankenfood Myth: How Protest and Politics Threaten the Biotech Revolution. ABC-CLIO, Inc., New York.

Ministerio de medio ambiente y medio rural y marino. Spain 2011. Planes de seguimiento ambiental del cultiva de maiz modificado geneticamente en España, pp. 72. Available at: http://www.marm.es/es/calidad-y-evaluacion-ambiental/ temas/biotecnologia/PLAN_DE_SEGUIMIENTO_ mar_2011_tcm7-147305.pdf [accessed 1 May 2012].

Montfort, P.-F. 2008. The U.S. Senate denounces excessive speculation on agricultural futures markets. Report from the U.S. Senate permanent subcommittee on investigations (momagri). Available at: http://www.momagri.org/UK/ focus-on-issues/The-U-S-Senate-denounces-excessivespeculation-on-agricultural-futures-markets_538.html [accessed 1 May 2012].

Monkemeyer W., Schmidt K., Beissner L., Schiemann J. and Wilhelm R. 2006. A critical examination of the potentials of existing German networks for GMO monitoring. J. Verbrauch. Lebensmittel., 1: 67-71.

Monsanto Co. 2009a. Annual monitoring report on the cultivation of MON 810 in 2008. Czech Republic, Germany, Portugal, Slovakia, Poland, Romania and Spain. pp. 388. Available at: http://apps2.bvl.bund.de/bbregwww/doc.do? id=78 [accessed 1 May 2012].

Monsanto Co. 2009b. Monitoring report. MON 810 cultivation. Spain. 2003-2004. pp. 57. Available at: https:// yieldgard.eu/ [accessed 1 May 2012].

Moose S.P. and Mumm R.H. 2008. Molecular plant breeding as the foundation for 21 st century crop Improvement. Plant Physiol., 147: 969-977.

Morris E. 2011. A semi-quantitative approach to GMO riskbenefit analysis. Transgenic Res., 20: 1055-1071.

Motion J. and Doolin B. 2007. Out of the laboratory: scientists' discursive practices in their encounters with activists. Discourse Stud., 9: 63-85.

Muller P. 1995. Les politiques publiques comme construction d'un rapport au monde. In: A. Faure, G. Pollet and P. Warin (eds). La construction du sens dans les politiques publiques, L'Harmattan, Paris, France, pp. 153-179.

Nagarajan S. and Singh D.V. 1990. Long-distance dispersion of rust pathogens. Annu. Rev. Phytopathol., 28: 139-153.

OECD. 2011. OECD scheme for the varietal certification of maize and sorghum seeds moving in international trade.
2011. C(2000)146/FINAL incl. 2003, 2004, 2005, 2006, 2007, 2008, 2009 \& 2010 amendments OECD seed schems - January 2011. Annex XI to the decision. OECD (ed.). OECD, Paris, France. pp. 12. Available at: http://www. oecd.org/dataoecd/23/59/44594184.pdf [accessed 1 May 2012].

Ong E.K. and Glantz S.A. 2001. Constructing 'sound science' and 'good epidemiology': tobacco, lawyers, and public relations firms. Am. J. Public Health, 91: 1749-1757.

Osman A. and Chable V. 2009. Inventory of initiatives on seeds of landraces in Europe. J. Agr. Environ. Internat. Dev., 103: 95-130.

Paillard S. and Treyer S. 2010. Nourrir la planète: deux scénarios. Agrimonde et le débat sur l'avenir de l'agriculture et de l'alimentation à l'échelle mondiale. Futuribles, 364: 45-64.

Paillard S., Treyer S. and Dorin B. (eds.). 2011. Agrimonde. Scenarios and Challenges for Feeding the World in 2050. Editions Quae, Versailles, France.

Palaudelmàs M., Melé E., Monfort A., Serra J., Salvia J. and Messeguer J. In Press. Assessment of the influence of field size on maize gene flow using SSR analysis. Transgenic Res., 1-13.

Pan Z., Yang X.B., Pivonia S., Xue L., Pasken R. and Roads J. 2006. Long-term prediction of soybean rust entry into the continental United States. Plant Dis., 90: 840-846.

Paré-Chamontin A. 2010. Contribution au développement d'une organisation vigilante. Cas de la détection d'organismes nuisibles aux végétaux agricoles en France métropolitaine. In: Institut des Sciences et Industries du Vivant et de l'Environnement Ecole doctorale ABIES., AgroParisTech (formerly INA P-G) Paris, France. pp. 234. Available at: http://www1.montpellier.inra.fr/CBGP/ BemisiaRisk/These-APC-2010.pdf [accessed 1 May 2012].

Pascher K., Moser D., Dullinger S., Sachslehner L., Gros P., Sauberer N., Traxler A., Grabherr G. and Frank T. 2011. Setup, efforts and practical experiences of a monitoring program for genetically modified plants - an Austrian case study for oilseed rape and maize. Environ. Sci. Euro., 23: $1-21$.

Paul H., Steinbrecher R., Kuyek D. and Michaels L. 2003. Hungry Corporations: Transnational Biotech Companies Colonise the Food Chain. Zed Books, London, UK.

Perkowski M. 2011. USDA weighs biotech compensation plan. Capital Press (ed.). Available at: http://www. capitalpress.com/mp-biotech-compensation-111811 [accessed 1 May 2012].

Pietola K., Myyrä S. and Heikkilä A.-M. 2011. The penetration of financial instability in agricultural credit and leveraging. In Factor Markets Comparative analysis of factor markets fro agriculture across the Member states 245123-FP7-KBBE-2009-3. Available at: http://www. 
ceps.be/system/files/book/2011/09/Factor\%20Markets\%20 WP\%20No\%202\%20Pietola\%20et\%20al.pdf [accessed 1 May 2012].

Prat F. 2011. OGM: la bataille de l'information. Editions Charles Léopold Mayer, Paris, France.

Public Health Agency of Canada. 2002. Conference proceedings ot the international conference on post-market surveillance of genetically modified foods. Paper presented at:International Conference on Past-market surveillance of genetically modified foods. Centre for surveillance Coordination. Ottawa, Canada. Available at: http://www.phacaspc.gc.ca/publicat/gmfcp-agmrc/index-eng.php [accessed 1 May 2012].

Reuter H., Middelhoff U., Graef F., Verhoeven R., Batz T., Weis M., Schmidt G., Schröder W. and Breckling B. 2010. Information system for monitoring environmental impacts of genetically modified organisms. Environ. Sci. Pollut. Res., 17: 1479-1490.

Reynolds M. 2004. How does Monsanto do it? An ethnographic case study of an advertising campaign. Interdisciplinary Journal for the Study of Discourse, 24: 329352.

Richard A. 2011. Comment les Français regardent la science [How French citizens look at Science]. La Recherche, 455: 84-88.

Russo P.S. 2009. Territoires, institutions et politiques publiques en matière de biotechnologies agricoles: les OGM en grande culture. Etude comparée France (Moyenne Garonne)/Italie (Emilie-Romagne). UFR 'Terrtoires Environnements Société' / Scuola di Dottorato in Economia e Statistica Agroalimentare. Université Paris-8- VincnnesSaint-Denis and Universita degli studi di Bologna Alma Mater studiorum, Paris, France and Bologna, Italy.

Ruttan V.W. 2004. Controversy about agricultural technology lessons from the green revolution. Int. J. Biotechnol., 6: 43-54.

Ruttink T., Demeyer R., Van Gulck E., Van Droogenbroeck B., Querci M., Taverniers I. and De Loose M. 2010a. Molecular toolbox for the identification of unknown genetically modified organisms. Anal. Bioanal. Chem., 396: 2073-2089.

Ruttink T., Morisset D., Van Droogenbroeck B., Lavrac N., Van den Eede G.L.M., Zel J., and De Loose M. 2010b. Knowledge-technology-based discovery of unauthorized genetically modified organisms. Anal. Bioanal. Chem., 396: 1951-1959.

Sanvido O., Romeis J. and Bigler F. 2007. Ecological impacts of genetically modified crops: ten years of field research and commercial cultivation. Adv. Biochem. Eng. Biot., 107: 235-278.

Sanvido O., Romeis, J. and Bigler F. 2011. Environmental change challenges decision-making during post-market environmental monitoring of transgenic crops. Transgenic Res., 20: 1191-1201.
Sauvy A. 1949. Le 'faux problème' de la population mondiale. Population, 3: 447-462.

Schafer M.G., Ross A.X., Londo J.P., Burdick C.A., Lee E.H., Travers S.E., Water P.K.V.d. and Sagers C.L. 2010. Evidence for the establishment and persistence of genetically modified canola populations in the U.S. Paper presented at: The 95th ESA Annual Meeting (Pittsburgh, Pennsylvania, USA). Available at: http://eco.confex. com/eco/2010/techprogram/P27199.HTM [accessed 1 May 2012].

Schmeller D.S. and Henle K. 2008. Cultivation of genetically modified organisms: resource needs for monitoring adverse effects on biodiversity. Biodivers. Conserv., 17: 35513558.

Schmidt K., Wilhelm R., Schmidtke J., Beissner L., Moenkemeyer W., Boettinger P., Sweet J. and Schiemann J. 2008. Farm questionnaires for monitoring genetically modified crops: a case study using GM maize. Environ. Biosafety Res., 7: 163-179.

Schmidtke J. and Schmidt K. 2007. Use of existing networks for the General Surveillance of GMP? Proposal of a reporting system and a Central Reporting Office. J. Verbraucher. Lebensmittels., 2: 79-84.

Searchinger T., Heimlich R., Houghton R.A., Dong F., Elobeid A., Fabiosa J., Tokgoz S., Hayes D. and Yu T.-H. 2008. Use of U.S. croplands for biofuels increases greenhouse gases through emissions from land-use change. Science, 319: 1238-1240.

Seifert F. 2006. Upper Austria's ban on genetically modified organisms - Predictable failure, unusual alliances. SwsRundschau, 46: 409-431.

Seifert F. 2009. Consensual NIMBYs, contentious NIABYs: explaining contrasting forms of farmers GMO opposition in Austria and France. Sociol. Ruralis, 49: 20-40.

Shepard L.E. and Collins R.A. 1982. Why do farmers fail? Farm bankruptcies 1910-78. Am. J. Agr. Econ., 64: 609-615.

Smit E., Bakker P.A.H.M., Bergmans H., Bloem J., Griffiths B.S., Rutgers M., Sanvido O., Singh B.K., van Veen H., Wilhelm R. and Glandorf D.C.M. 2012. General surveillance of the soil ecosystem: an approach to monitoring unexpected adverse effects of GMO's. Ecol. Indic., 14: 107-113.

Smyth S.J. and Kershen D.L. 2006. Agricultural biotechnology: legal liability regimes from comparative and international perspectives. Global Jurist, 6: art3.

Spök A. 2007. Molecular farming on the rise - GMO regulators still walking a tightrope. Trends Biotechnol., 25: $74-82$.

Swaminathan M.S. 2010. Achieving food security in times of crisis. New Biotechnol., 27: 453-460.

Tadele Z. 2009. Role of orphan crops in enhancing and diversifying food production in Africa. African Technology Development Forum Journal, 6: 9-15. 
Tengs T., Kristoffersen A.B., Zhang H.B., Berdal K.G., Lovoll M. and Holst-Jensen A. 2010. Non-prejudiced detection and characterization of genetic modifications. Food Anal. Met., 3: 120-128.

Tinland B., Janssens J., Lecoq E., Legris G., Matzk A., Pleysier A., Wandelt C. and Willekens H. 2006. Implementation of general surveillance in Europe: the industry perspective. J. Verbrauch. Lebensmittels., 1: 42-44.

Turner S. 2001. What is the problem with experts? Soc. Stud. Sci., 31: 123-149.

UNFPA (United Nations Population Fund). 2011. People and possibilities in a world of 7 billion, UNFPA (ed.). pp. 132. Available at: http://foweb.unfpa.org/SWP2011/reports/ENSWOP2011-FINAL.pdf [accessed 1 May 2012].

United nations Conference on Trade and Development. 2011a. Commodities at a glance, UNCATD, (ed.). United Nations Conference on Trade and Development, Geneva, Switzerland. pp. 26. Available at: http://www.unctad.org/ en/docs/suc20112_en.pdf [accessed 1 May 2012].

United Nations Conference on Trade and Development. 2011b. Recent developments in key commodity markets: trends and challenges. Note by the UNCTAD secretariat (United Nations Organization). pp. 19. Available at: http://www.unctad.info/upload/SUC/MYEM2011/Trends_ Challenges.pdf [accessed 1 May 2012].

Van de Water P.K., Watrud L.S., Lee E.H., Burdick C. and King G.A. 2007. Long-distance GM pollen movement of creeping bentgrass using modeled wind trajectory analysis. Ecol. Appl., 17: 1244-1256.

van de Wiel C.C.M., van den Brink L., Bus C.B., Riemens M.M., Lotz L.A.P. and Smulders M.J.M. 2011. Crop volunteers and climate change. Effects of future climate change on the occurrence of maize, sugar beet and potato volunteers in the Netherlands. COGEM (ed.). pp. 52. Available at: http://www.cogem.net/index.cfm/en/publications/ publicatie/crop-volunteers-and-climate-change-effects-offuture-climate-change-on-the-occurrence-of-maize-sugarbeet-and-potato-volunteers-in-the-netherlands [accessed 1 May 2012].

van den Belt H. 2003. Debating the precautionary principle: 'guilty until proven innocent' or 'innocent until proven guilty"? Plant Physiol., 132: 1122-1126.

van den Brink L., Bus C.B., Franke A.C., Groten J.A.M., Lotz L.A.P., Trimmer R.D. and van de Wiel, C.C.M. 2010. Inventory of observed unexpected environmental effects of genetically modified crops, Applied Plant Research, DLO foundation (ed.). DLO Foundation, Applied Plant Research Wageningen, The Netherlands. COGEM document. pp. 80. Available at: http://www.cogem.net/ContentFiles/ CGM\%202010-08\%20Unexpected\%20environmental\%20 effects.pdf [accessed 1 May 2012].

Vaucheret H. and Chupeau Y. 2012. Ingested plant miRNAs regulate gene expression in animals. Cell Res., 22:
Viaud V., Monod H., Lavigne C., Angevin F. and Adamczyk K. 2008. Spatial sensitivity of maize gene-flow to landscape pattern: a simulation approach. Landscape Ecol., 23: 1067-1079.

Vieille Blanchard, E. 2010. Modelling the future: an overview of the 'Limits to growth' debate. Centaurus, 52: 91-116.

Viner B.J. and Arritt R.W. 2010. Increased pollen viability resulting from transport to the upper boundary layer. Field Crops Res., 119: 195-200.

Vos, E., ed. 2008. European risk governance. Its science, its inclusiveness and its effectiveness. CONNEX Report Series No 06. CONNEX Research Project. Available at: http:// www.clingendael.nl/cesp/staff/aschout/20080200_cesp_ chapter_schout_connex.pdf\#page $=45$ [accessed 1 May 2012].

Wal J.M., Hepburn P.A., Lea L.J. and Crevel R.W.R. 2003. Post-market surveillance of GM foods: applicability and limitations of schemes used with pharmaceuticals and some non-GM novel foods. Regul. Toxicol. Pharm., 38: 98-104.

Wallach D., Makowski D. and Jones J.W. (eds). 2006. Working with Dynamic Crop Models. Evaluation, Analysis, Parametrization and Applications. Elsevier, Amsterdam, The Netherlands.

Weekes R., Allnutt T., Boffey C., Morgan S., Bilton M., Daniels R. and Henry C. 2007. A study of crop-to-crop gene flow using farm scale sites of fodder maize (Zea mays L.) in the UK. Transgenic Res., 16: 203-211.

Wertz M.S., Kyriss T., Paranjape, S. and Glantz S.A. 2011. The toxic effects of cigarette additives. Philip Morris' project Mix reconsidered: an analysis of documents released through litigation. PLoS Med., 8: e1001145.

Westbrook J.K. and Isard S.A. 1999. Atmospheric scales of biotic dispersal. Agr. Forest Meteorol., 97: 263-274.

Wilhelm R., Sanvido O., Castanera P., Schmidt K. and Schiemann J. 2009. Monitoring the commercial cultivation of Bt maize in Europe - conclusions and recommendations for future monitoring practice. Environ. Biosafety Res., 8: 219-225.

Wolf S. 2008. Professionalization of agriculture and distributed innovation for multifunctional landscapes and territorial development. Agr. Hum. Values, 25: 203-207.

Wolt J.D., Keese P., Raybould A., Fitzpatrick J.W., Burachik M., Gray A., Olin S.S., Schiemann J., Sears M. and Wu F. 2010. Problem formulation in the environmental risk assessment for genetically modified plants. Transgenic Res., 19: 425-436.

Young C.E. and Westcott P.C. 2000. How decoupled is U.S. agricultural support for major crops? Am. J. Agr. Econ., 82: 762-767.

Zhang L., Hou D., Chen X., Li D., Zhu L., Zhang Y., Li J., Bian Z., Liang X., Cai X., Yin, Y., Wang, C., Zhang, T., Zhu, D., Zhang, D., Xu, J., Chen, Q., Ba, Y., Liu, J., Wang, 
Q., Chen, J., Wang, J., Wang, M., Zhang, Q., Zhang, J., Zen, K., Zhang, C-Y. 2012. Exogenous plant MIR168a specifically targets mammalian LDLRAP1: evidence of crosskingdom regulation by microRNA. Cell Res., 22(1): 107-126.

Zughart W., Benzler A., Berhorn F., Sukopp U. and Graef F. 2008. Determining indicators, methods and sites for monitoring potential adverse effects of genetically modified plants to the environment: the legal and conceptional framework for implementation. Euphytica, 164: 845852.

Yamamura K. 2004. Dispersal distance of corn pollen under fluctuating diffusion coefficient. Popul. Ecol., 46: 87-101. 